\title{
Impacts of aerosol-monsoon interaction on rainfall and circulation over Northern India and the Himalaya Foothills
}

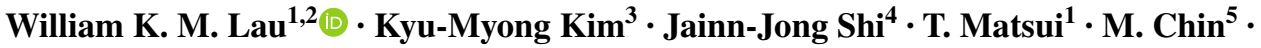

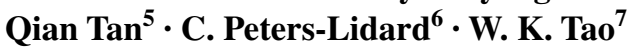

Received: 21 July 2016 / Accepted: 27 October 2016 / Published online: 4 November 2016

(C) The Author(s) 2016. This article is published with open access at Springerlink.com

\begin{abstract}
The boreal summer of 2008 was unusual for the Indian monsoon, featuring exceptional heavy loading of dust aerosols over the Arabian Sea and northern-central India, near normal all-India rainfall, but excessive heavy rain, causing disastrous flooding in the Northern Indian Himalaya Foothills (NIHF) regions, accompanied by persistent drought conditions in central and southern India. Using the NASA Unified-physics Weather Research Forecast (NUWRF) model with fully interactive aerosol physics and dynamics, we carried out three sets of 7-day ensemble model forecast experiments: (1) control with no aerosol, (2)
\end{abstract}

Electronic supplementary material The online version of this article (doi:10.1007/s00382-016-3430-y) contains supplementary material, which is available to authorized users.

William K. M. Lau

wkmlau@umd.edu

1 Earth System Science Interdisciplinary Center (ESSIC), University of Maryland, College Park, MD 20740, USA

2 Department of Atmospheric Sciences, University of Texas, College Station, TX 77843, USA

3 Climate and Radiation Laboratory, Earth Science Division, Goddard Space Flight Center, Greenbelt, MD 20771, USA

4 Goddard Earth Science Technology, Application Research (GESTAR), Morgan State University, Baltimore, MD 21251, USA

5 Atmospheric Chemistry and Dynamics Laboratory, Earth Science Division, Goddard Space Flight Center, Greenbelt, MD 20771, USA

6 Earth Science Division, Goddard Space Flight Center, Greenbelt, MD 20771, USA

7 Mesoscale Atmospheric Processes Laboratory, Earth Science Division, Goddard Space Flight Center, Greenbelt, MD 20771, USA aerosol radiative effect only and (3) aerosol radiative and aerosol-cloud-microphysics effects, to study the impacts of aerosol-monsoon interactions on monsoon variability over the NIHF during the summer of 2008. Results show that aerosol-radiation interaction (ARI), i.e., dust aerosol transport, and dynamical feedback processes induced by aerosolradiative heating, plays a key role in altering the large-scale monsoon circulation system, reflected by an increased northsouth tropospheric temperature gradient, a northward shift of heavy monsoon rainfall, advancing the monsoon onset by 1-5 days over the HF, consistent with the EHP hypothesis (Lau et al. in Clim Dyn 26(7-8):855-864, 2006). Additionally, we found that dust aerosols, via the semi-direct effect, increase atmospheric stability, and cause the dissipation of a developing monsoon onset cyclone over northeastern India/ northern Bay of Bengal. Eventually, in a matter of several days, ARI transforms the developing monsoon cyclone into meso-scale convective cells along the HF slopes. AerosolCloud-microphysics Interaction (ACI) further enhances the ARI effect in invigorating the deep convection cells and speeding up the transformation processes. Results indicate that even in short-term (up to weekly) numerical forecasting of monsoon circulation and rainfall, effects of aerosol-monsoon interaction can be substantial and cannot be ignored.

\section{Introduction}

The Northern India and Himalayan foothills (NIHF) region is an essential component of the Indian monsoon (Gadgil et al. 2003). Summer monsoon rainfall over this region feeds the Ganges, and the Indus rivers, providing fresh water essential for agriculture, industrial and livelihood over hundreds of millions people in the region. The Himalayan foothills (HF), an escarpment that rises to over $5 \mathrm{~km}$ 
above the Indo-Gangetic Plain (IGP) over Northern India (NI), provides a major barrier to the northward advance of the Indian monsoon rainfall, as well as contributing to the thermal contrast between the Tibetan Plateau and the Indian Ocean (Boos and Kuang 2010; Wu et al. 2012). It also provides strong orographic forcing to the prevailing southwesterly monsoon flow, giving rise to strong vertical ascent and development of vigorous thunderstorm cells with intense precipitation during the monsoon season (Houze et al. 2007; Rasmussen and Houze 2012; Das et al. 2014). The importance of the NIHF orography in forcing strong convection and extreme precipitations, in relationship to the large-scale Indian monsoon has also been reported (Barros and Lang 2003; Barros and Lattenmaier 1994).

Recently, an increasing number of studies have suggested that absorbing aerosols (mainly desert dusts and carbonaceous aerosols) can affect the interannual and intraseasonal variability of the Indian monsoon rainfall (Lau et al. 2006; Lau and Kim 2006; Lau 2014; Manoj et al. 2011; Hazra et al. 2013; Vinoj et al. 2014; Kim et al. 2015; D'Errico et al. 2015; Sanap and Pandithurai 2015, and many others). Based on these studies, Lau (2016) has proposed a new paradigm arguing that natural aerosol, particularly dust and carbonaceous aerosols from natural sources should be considered an essential component of an intrinsic aerosol-monsoon weather and climate system. Specifically for the NIHF region, the Elevated Heat Pump (EHP) hypothesis (Lau et al. 2006) posited that through atmospheric diabatic heating and circulation feedbacks, atmospheric heating due to absorbing aerosols from both anthropogenic and natural sources accumulated over the Indo-Gangetic Plain during the pre-monsoon period can, lead to increased rainfall and advance of the monsoon rainy season over the NIHF. At present, effects of absorbing aerosols in increasing monsoon rainfall and circulation consistent with EHP, but with significantly different regional spatial and temporal details have been found in many global climate models (Lau et al. 2006; Meehl et al. 2008; Randles and Ramaswamy 2008; Wang et al. 2009; Collier and Zhang 2009; Henriksson et al. 2014; D'Errico et al. 2015; Jin et al. 2015). One of the main reasons for the regional differences is that state-of-the-art climate models, due to their coarse resolution generally, are still unable to resolve the complex topography and interactions of monsoon winds, precipitation and aerosol transport, sources and sink processes over the NIHF. For more realistic simulations, the use of high-resolution regional atmospheric model with realistic representation of aerosol and monsoon processes is required. In this paper, using the NASA Unified Physics Weather Research Forecast (NU-WRF) model, we have carried out numerical experiments aimed at providing a better understanding of the physical processes involved in aerosol-monsoon interactions, including aerosol radiative and microphysical effects, as well as induced dynamical feedbacks over the complex topography of the NIHF region. The experiments will be conducted based on a case study of the 2008 Indian monsoon.

\subsection{The 2008 Indian monsoon}

The all-Indian monsoon rainfall for the full monsoon season (June-September) during 2008 was near normal. However, rainfall was excessive in the north, but deficient in the central and southern India for most of the season (Rao et al. 2011). Abnormally heavy rain started in early June, and lasted through early August. The heavy rainfall eventually led to the breaching of the Kosi river in early August, with disastrous flooding over Nepal and many states in northern India including, Assam, Andhra Pradesh, Bihar, Maharashtra, Uttar Pradesh, West Bengal and Orissa. The flood affected over 2.3 million people in the northern part of the state of Bihar, prompting the Indian government to declare a national disaster. The heavy rain in June (Fig. 1a) was found mainly over NIHF, extending southeastward toward the Bay of Bengal. At the same time, rainfall was suppressed over southwestern, central and southern, and extreme northeastern India. The summer of 2008 also witnessed an early onset of the monsoon over northern India (Tyagi et al. 2009). Most interesting, it was also a year with unusually large loading of aerosols over the Arabian Sea, northwestern India, and across central Indian during the early monsoon season (Fig. 1b). In this study, we will examine the possible roles of aerosols in influencing this rather unusual Indian monsoon.

\section{Modeling strategy and methodology}

We use the NASA Unified physics Weather Research Forecast (NUWRF) regional atmospheric model to carry out ensemble forecast experiments to investigate the role of aerosol-monsoon dynamic interaction in the NIHF region. NUWRF has been developed at GSFC to unify physics in WRF with NASA's current physics package for aerosol and cloud microphysics, as well as assimilation systems, common to GEOS-5, the Goddard Cumulus Ensemble cloud model (GCE) (Tao et al. 2009), the Goddard Chemistry and Radiation Transport (GOCART) model (Chin et al. 2004, 2009, 2014; Ginoux et al. 2001), and the Land data Information System (LIS) (Peters-Lidard et al. 2007, 2015; Tao et al. 2013; Lang et al. 2014; Shi et al. 2014). Briefly, GOCART uses the following modules in aerosol simulation: emission, which includes dust, sulfur, black carbon, organic carbon, and sea-salt emissions; chemistry, which includes in-air and in-cloud oxidations of sulfate precursors $\left(\mathrm{SO}_{2}\right.$ and DMS); turbulent dry deposition, which is 


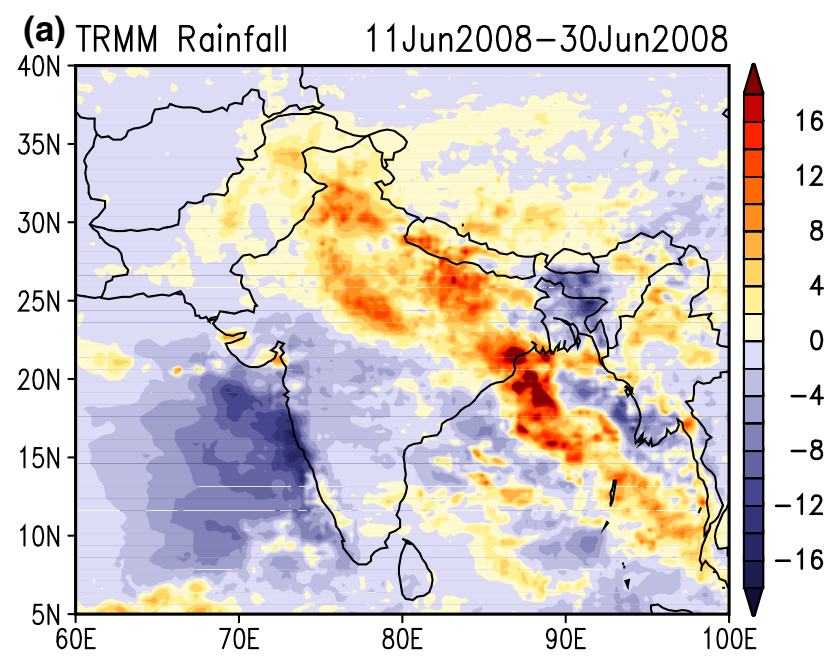

(b) MODIS AOD

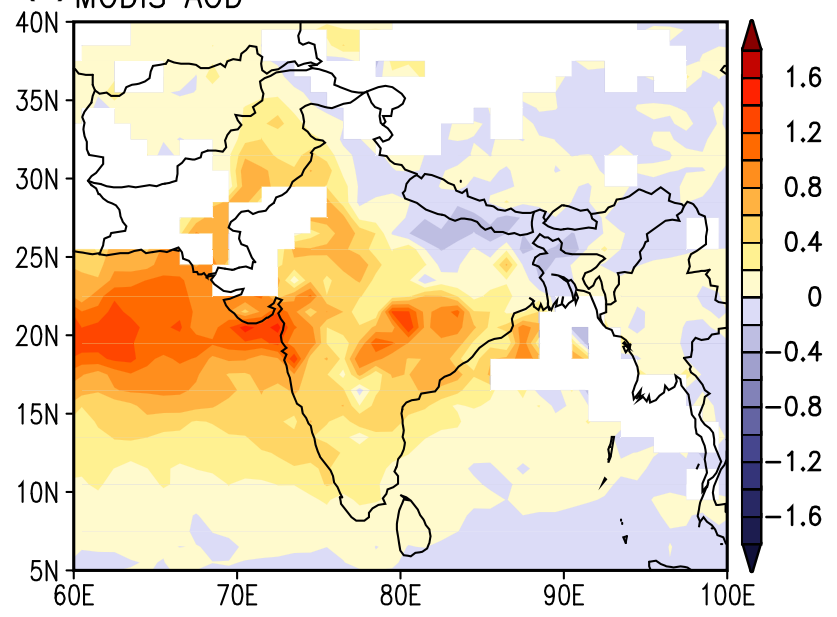

Fig. 1 Spatial distribution of observed a rainfall anomalis $\left(\mathrm{mm}\right.$ day $^{-1}$ ) from TRMM and $\mathbf{b}$ AOD from MODIS, for the Indian monsoon during June 2008. Rainfall anomalies are computed relative to $1998-2013$ climatology

calculated by aerodynamic resistance; gravitational settling, which is a function of air viscosity and particle size; and wet deposition, which accounts for the scavenging of soluble species in convective updrafts and rainout/washout in large-scale precipitation.

Dust size distribution is calculated by solving the continuity equation for eight size bins ranging from 0.1 to $10 \mu \mathrm{m}$ in radii, representing mineral dust types from fine clay to coarse sand particles. The continuity equation includes macroscopic advection by winds, parameterized eddy diffusion and moist convection. The removal mechanisms include dry deposition at the surface by impaction, wet deposition in and below clouds, and gravitational settling. Dust emission is computed as a function of the surface wind at $10 \mathrm{~m}$, a threshold frictional velocity, and a source function which is depended on geographic locations and dust sizes (Ginoux et al. 2001; Gillette and Passi 1988).
For aerosol-cloud microphysics, NUWRF computes cloud droplet concentration using aerosol mass directly predicted by GOCART/WRF-Chem at each time step. For a given air temperature and supersaturation, cloud condensation nuclei $(\mathrm{CCN})$ is calculated from the aerosol species predicted by GOCART based on the Koehler curve (Koehler et al. 2006; Andreae and Rosenfeld 2008), while the concentration of ice nuclei (IN) is obtained following the approach of Demott et al. (2010). Both CCN and IN are diagnostic parameters calculated from the WRF-Chem/ GOCART-predicted aerosol mass concentrations in the Goddard one-moment microphysics scheme. $\mathrm{CCN}$ is used to calculate the auto-conversion of cloud liquid water $\left(\mathrm{Q}_{\mathrm{c}}\right)$ to rain water $\left(\mathrm{Q}_{\mathrm{r}}\right)$ following Liu and Daum (2004), while IN is used to calculate 1$)$ the conversion of cloud ice $\left(Q_{i}\right)$ to snow $\left(\mathrm{Q}_{\mathrm{s}}\right)$ due to the Bergeron process and 2) the growth of cloud liquid water $\left(\mathrm{Q}_{c}\right)$ to cloud ice $\left(\mathrm{Q}_{\mathrm{i}}\right)$ due to deposition.

The NUWRF team has also coupled GOCART with LIS which provides key information (e.g., soil moisture and soil porosity) that GOCART uses to calculate dust emissions. GOCART has also been coupled with the Goddard radiation and microphysics scheme to simulate the direct and indirect aerosol effects on energy budget, cloud, and precipitation. Parameterization schemes to estimate biogenic secondary organic aerosols have also been integrated from WRF/Chem into NUWRF. In addition, several model utilities have been developed and modified to facilitate NUWRF applications, including implementation of time varying GOCART aerosols types and distribution as initial and boundary conditions, and incorporation of pollutant emissions inventories for both anthropogenic and natural sources. For the present experiments, the single scattering albedo of dust aerosol at the visible band $(0.4-0.7 \mu \mathrm{m})$ were specified in the range 0.95 to 0.79 , representing 8 size categories of dust from fine clay to coarse dust particles. The much higher absorption (lower single scattering albedo) for larger size particles is consistent with recent observations indicating coating of fine black carbon particle on the larger size sand particles in Asian monsoon regions (Ganguly et al. 2005; Satheesh et al. 2008; Eck et al. 2010).

For our model experiments, we followed the ensemble forecast methodology commonly used in monsoon numerical weather prediction up to a week to investigate the impacts of aerosol-monsoon dynamic interaction on short time scales. We used nested domains with $9 \mathrm{~km}$ resolution in an inner domain $\left(60^{\circ}-100^{\circ} \mathrm{E}, 10^{\circ}-40^{\circ} \mathrm{N}\right)$ covering the Indian subcontinent and eastern Indo-China, and an outer domain with $27 \mathrm{~km}$ resolution, spanning the large-scale monsoon domain $\left(40-120^{\circ} \mathrm{E}, 5^{\circ} \mathrm{S}-40^{\circ} \mathrm{N}\right)$, with 61 layers in the vertical (Fig. S1). We selected the early monsoon period June 1-July 152008 for our study. This period covered the monsoon onset transition phase (June 11-17), and several subsequent heavy rain events over NIHF (See discussion in 
Sect. 3.2). We carried out 45, 7-day forecast experiments forced by prescribed observed sea surface temperature, and with atmospheric and aerosol boundary conditions initialized at intervals of one day starting from June 1, first with no aerosol (NA) effects, which is still the common practice for most numerical weather forecasts in monsoon regions (Krishnamurti et al. 1991). A second identical set of experiments was carried out but with the inclusion of aerosol radiative (RAD) effect. A third set of experiments same as the control, except with both aerosol radiative and microphysics interactive effects (RADM) were carried out for the onset period June 11-17. Initial and boundary conditions for meteorology and aerosols were obtained respectively from NCEP GFS $1^{\circ} \times 1^{\circ}$ global analysis, and from GOCART. By comparing the RAD and RADM to NA forecasts over the NIHF region in a realistic setting with a high-resolution regional model and sophisticated aerosol physics, we can gain a better understanding of intrinsic, aerosol-monsoon interaction for the Indian monsoon, involving no change in anthropogenic aerosol emissions. In following discussions, all model anomaly quantities are defined with respect to NA. For brevity, we shall refer to RAD anomalies as due to Aerosol-Radiative Interaction (ARI) effects. Effects of Aerosol-Cloud-microphysics-Interaction (ACI) will be diagnosed from comparison between RADM and RAD anomalies. Aerosol impacts will be examined using two different kinds of averaging. First, ensemble forecast averaging for day-1 through day-7 for a specific date, will be compared to observation to assess aerosol impacts on forecast skills. Second, ensemble averages of all forecasts as a function of forecast days, will be used to assess the aerosol impact as a function of forecast lead time. For comparing model results to observations, we use rainfall data from the Tropical Precipitation Measuring Mission (TRMM), and winds and temperature data from the NASA MERRA2, Modern Era Retrospective analysis for Research and Applications -version 2 (Bosilovich et al. 2015).

\section{Results}

To facilitate comparison of model results to observations, and set the stage for the model output analysis, a brief description of the observed large-scale features of the Indian monsoon of 2008 is presented first.

\subsection{Observed large-scale monsoon features during June 2008}

The excessive rainfall over northern India in June 2008 (see Fig. 1) was accompanied by an upper tropospheric (500-200 hPa) anomalous warming (deviation from climatological mean) northwest of the Indian subcontinent, and an anomalous large-scale anticyclone (Fig. 2a), with strong easterlies over northern Indian and the Arabian Sea (20$35 \mathrm{~N}$ ), consistent with thermal wind balance in an environment with positive temperature gradient (warmer-north and colder-south). The importance of the tropospheric temperature gradient in controlling the timing of the onset of the Indian monsoon is well known ( $\mathrm{Li}$ and Yanai 1996; Goswami and Xavier 2005; Wu et al. 2012). In the lower troposphere, an anomalous low-level cyclonic circulation cell was found over the northern Arabian Sea, coupled with an anticyclonic cell over southeastern India and the southern Bay of Bengal (Fig. 2b). Associated with these circulation cells were stronger low-level northeasterlies over the Arabian Peninsular and strengthened low-level southwesterlies over the Arabian Sea and westerlies over central India. The former would increase dust emission over the desert surface, and the latter would increase dust and moisture transport from the Arabian Sea to northern India. Strong anomalous cooling of the lower troposphere was found over the Indo-Gangetic Plain $\left(20^{\circ}-30^{\circ} \mathrm{N}\right)$, and anomalous warming above with maximum upper troposphere warming anchored over the Tibetan Plateau (Fig. 2c). These features were accompanied by anomalous ascending motions and increased water vapor over the NIHF with sinking motion and increased dryness over southern India, and northern Indian Ocean (Fig. 2c, d). Increased monsoon westerlies were found in the lower troposphere over central and Northern India, and enhanced easterlies, from the upper troposphere to near surface over the NIHF (Fig. 2d). The aforementioned anomalies signal an enhancement of the early part of the Indian monsoon consistent with the EHP effect due to dust aerosols (Lau et al. 2006, 2008; Lau and Kim 2006). It should be noted that spring and summer of 2008 coincided with the decay phase of the 2007-2008 La Nina, with significant anomalous cooling over the equatorial central and eastern Pacific and warming of the southern tropical Indian Ocean during the boreal spring and summer of 2008. These SST anomalies would have significantly influenced the aforementioned anomalies of the Indian monsoon (Rao et al. 2011; Kim et al. 2015). However, given the prescribed observed SST in the control experiment (NA), SST effects including possible impacts of aerosols on SST are already included in the prescribed observed SST and lateral boundary conditions in NA. Hence model differences (with respect to NA) will only be attributed to aerosol effects associated with aerosol-monsoon interaction on fast times scales, up to 7 days - the longest lead time chosen for the model forecast experiments.

\subsection{Impact on model forecasts}

Figure 3 compares the distribution of AOD, rainfall and $850 \mathrm{hPa}$ winds in NA with observed rainfall from TRMM, 
(a) $T 500-200$

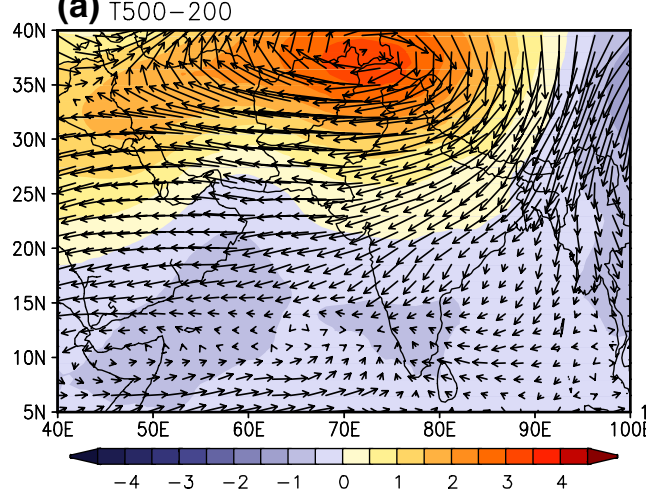

(b) $\mathrm{q} 1000-600$

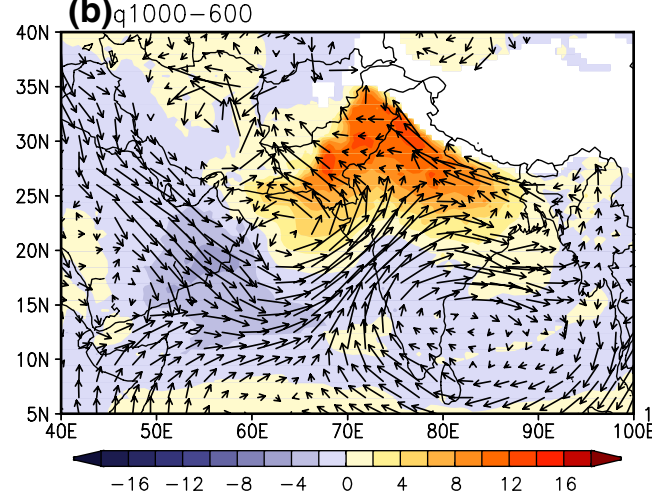

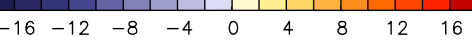

Fig. 2 Horizontal distribution of anomalies of a tropospheric temperature $\left({ }^{\circ} \mathrm{C}\right)$ and winds $\left(\mathrm{ms}^{-1}\right)$ averaged between $500-200 \mathrm{hPa}$, b $850 \mathrm{hPa}$ winds and specific humidity $\left(\mathrm{gKg}^{-1}\right)$ in the lower tropo-

AOD from MODIS, and winds from MERRA2 for the onset phase of the 2008 Indian monsoon (June 11-17). The NA experiment simulates the mean spatial distribution of aerosol AOD reasonably well compared to MODIS, featuring relatively high aerosol loading over the northern Arabian Sea, and northwestern Indo-Gangetic Plain, and low aerosol loading over northeastern India and the Bay of Bengal (Fig. 3). Overall, the AOD magnitude is underestimated, in some regions with only half the magnitude of MODIS AOD. An examination of the aerosol composition in GOCART has determined that a large-fraction of the AOD over the Arabian Sea and northwestern India and Pakistan is contributed mainly by desert dust (65-70\%) transported from the Middle East deserts and the Thar desert of northwestern Indian subcontinent.

The model mean rainfall and wind patterns show broad similarities to observations (Fig. 3c, d), but with notable differences. The model low-level westerlies are too strong. As a result, precipitation upwind over the mountain ridges of the Western Ghats, and Indo-China are overestimated. The model also missed the heavy rainfall band extending from the east coast of northern India into the Bay of Bengal. These are mostly due to the excessive monsoon low-level westerlies across central and southern India. As shown in

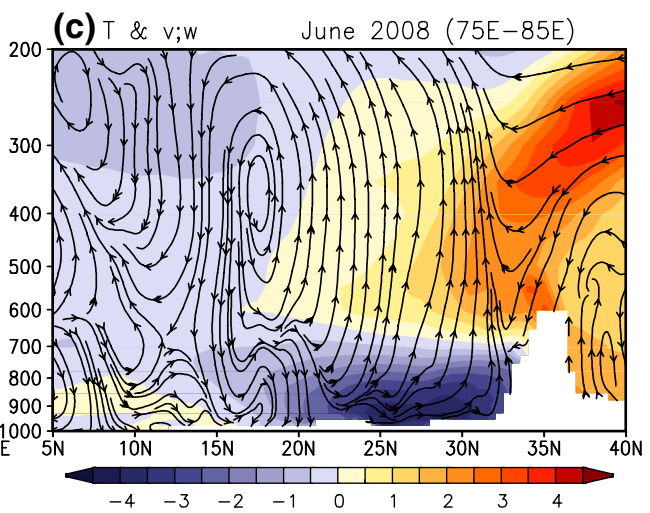

(d) $q \& u$

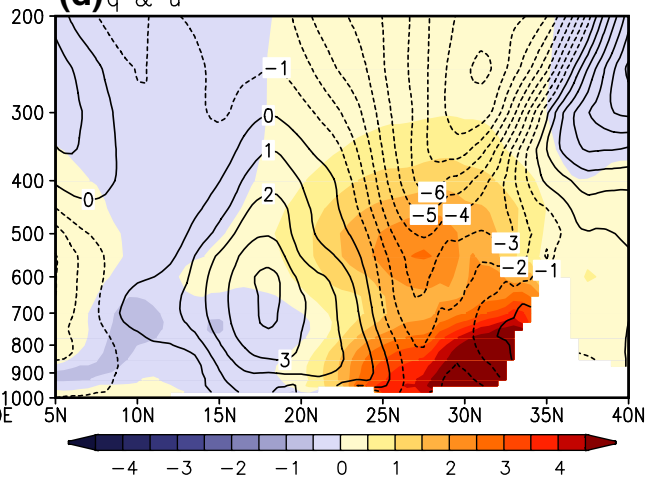

sphere (1000-600 hPa; and latitude-height cross-sections of $\mathbf{c}$ meridional overturning circulation (streamline) and temperature, and $\mathbf{d}$ zonal winds (contour) and specific humidity

following discussion, these biases are not related to model aerosol physics, because they are essential unchanged in the RAD and RADM simulations. Another notable feature is the excessive model rainfall over the southern IndoGangetic Plain, and deficient rainfall over the HF compared to TRMM. In the following, we will demonstrate how this bias is mitigated in the RAD and RADM experiments and how we can use the incremental improvement to explore the physical processes underlying aerosol-monsoon interactions over NIHF region. Despite the aforementioned discrepancies, the overall AOD and rainfall distributions in the model are consistent with dust aerosol emissions from the arid region of Southwest Asia, the Thar desert, and Middle East deserts and transport across the Arabia Sea, with strong wet removal in rainy regions.

Comparing the rainfall spatial distribution of RAD, and difference between RAD and NA (Fig. 4a, b) depicts a shift of the monsoon rain band from NI to HF during the onset phase, but little differences elsewhere. This means that given the largescale aerosol and meteorological initial condition, and on time scale of less than 7 days, aerosol-monsoon interaction effects are mostly found over the NIHF region. The latitudinal rainfall profile averaged over the $80^{\circ}-90^{\circ} \mathrm{E}$ sector shows clearly that the excessive NA model rainfall over the NI $\left(23^{\circ}-25^{\circ} \mathrm{N}\right)$, and 

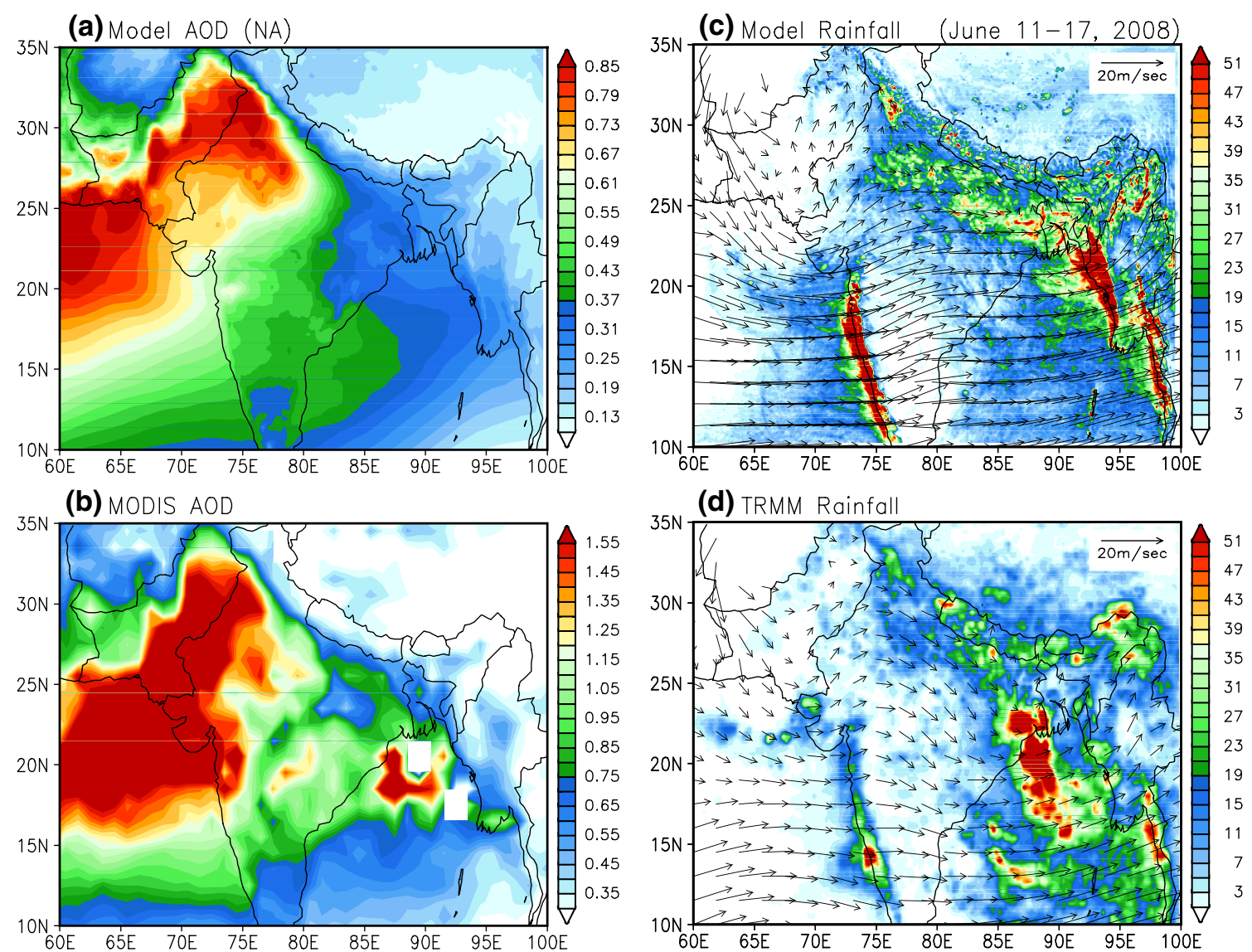

Fig. 3 Horizontal distribution of AOD a in control model simulation (NA), and $\mathbf{b}$ from MODIS observation. Rainfall and winds in $\mathbf{c}$ NA experiment, and $\mathbf{d}$ from TRMM, and MERRA2. Unit of rainfall in mm day ${ }^{-1}$, and winds in $\mathrm{ms}^{-1}$

deficient rainfall over the $\mathrm{HF}\left(25^{\circ}-30^{\circ} \mathrm{N}\right)$ compared to TRMM (Fig. 4c, d). ARI effects (Fig. 4e) clearly shift the onset maximum rainfall northward towards the $\mathrm{HF}$, mitigating but not completely removing the model rainfall bias.

To further assess the impacts of aerosol-monsoon interactions on the model forecasts, Fig. 5 shows the time series of the 1-7 days forecast rainfall, for NA and RAD, and TRMM, for the extended integration period through 1 June to July 15 over the northern domain (ND), and the southern domain (SD), defined along the curvature of the Himalaya mountain range (see domain marker in Fig. 4b) to better capture the rainfall anomaly along the HF, arising from aerosol-monsoon interaction. For the ND (Fig. 5a) the model forecasts show reasonable skills in capturing the major episodes of heavy rainfall events. However, after the onset, the model rainfall events tend to be overly active, with only much shallower breaks compared to TRMM observations. It is also noted that clear differences between RAD and NA forecasts tend to emerge after forecast day $3-4$, when the control by the initial conditions on the model forecasts are beginning to diminish. Beyond forecast day- 4 , the number of days with predicted increased rainfall is much higher than that with reduced rainfall, in RAD compared to NA, with a frequency ratio of approximately 2-to- 1 indicating a strong impact of absorbing aerosols in enhancing rainfall. The time series of the Day 5-7 mean forecasts (Fig. 5b) show clear enhanced rainfall in RAD relative to NA, during the on-set phase of rainfall events, indicating an advance ( 1-5 days) of the onset of monsoon rainfall over the ND (Fig. 5c) due to ARI. The rainfall enhancement and advance of rain events in ND can be seen to last through the entire month of June and to early July. Conversely over SD (Fig. 5c), rainfall is reduced in RAD compared to NA. Beyond forecast day4 , the number of days with reduced rainfall compared that with increased rainfall is approximately 9 to 1 , as a result of the northward shift of convection and rainfall away from the SD to the ND. Note that the SD experiences reduction in rainfall mostly during the peak and more often during the dissipation phase of the rainfall events (Fig. 5d).

\subsection{Large-scale interactions}

In this section, we explore aspects of aerosol-monsoon large-scale interaction, which governs the northward shift 


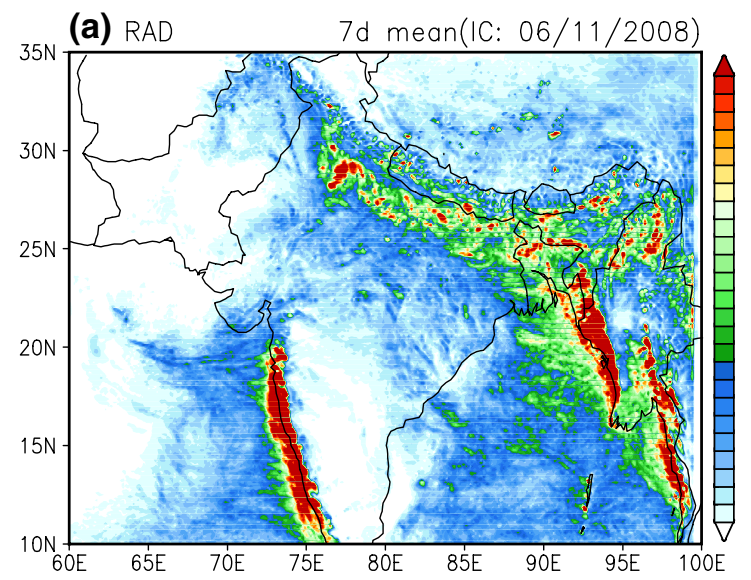

(b) RAD-NA

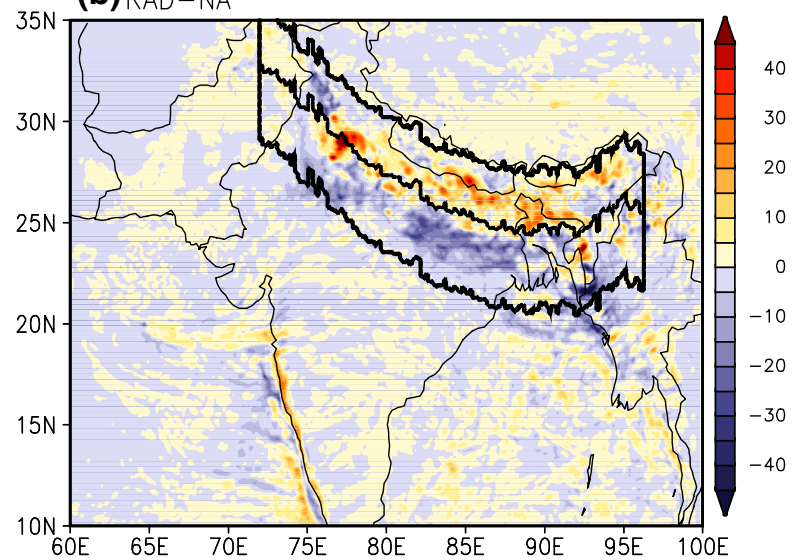

Fig. 4 Distribution of a total rainfall in RAD, b rainfall anomalies in RAD. Latitudinal profile of rainfall averaged between $80-90 \mathrm{E}$ in c TRMM observations, d NA, and e RAD, with positive (negative)

of rainfall from the SD to the ND. The variations of anomalous RAD rainfall and AOD are coherent (Fig. 6a), generally with enhanced rainfall in the ND region (north of $27^{\circ} \mathrm{N}$ ) where AOD is low, and suppressed rainfall in the regions of high AOD in the SD (south of $27^{\circ} \mathrm{N}$ ). This is consistent with increased wash out of aerosols in wet regions, and longer aerosol life times in more stable dry regions. Wind anomalies (Fig. 6b) show a rapid strengthening and northward displacement of westerlies and southerlies in the SD accompanying the monsoon onset over the ND, starting around June 16. This is followed by a major event during June 17-21 with increase in AOD, strengthening southwesteries in the SD coupled to enhanced rainfall in the ND. A similar event involving coherent variations of rainfall, AOD and winds took place during July 3-6. Note that anomalous low-level southerlies after the monsoon onset ( June 16) remain unchanged in sign, extending across approximately $27^{\circ} \mathrm{N}$, from the SD to the ND. This means that the ambient moisture in the SD is being advected northward by the strengthened southerlies, thus increasing (decreasing) atmospheric moisture in the ND (SD). The resulting

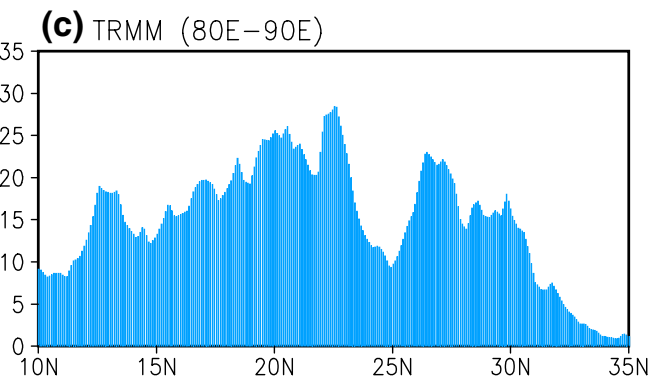

(d) $\mathrm{NA}$

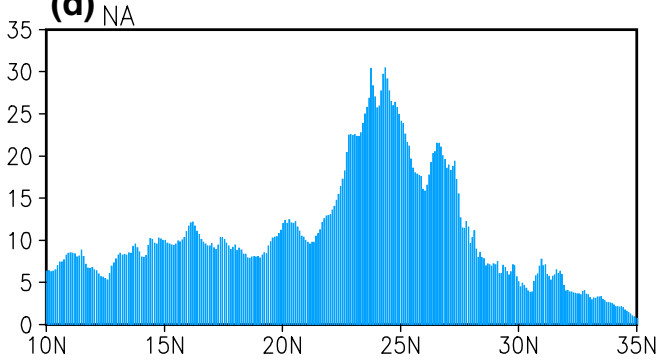

(e) RAD and NA

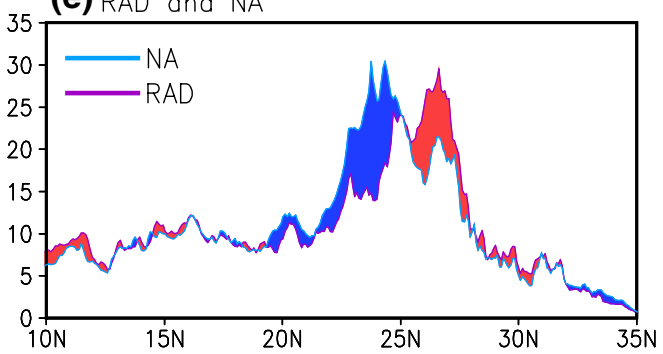

RAD-minus-NA differences indicated by red (blue) shading. The boundaries of Northern and Southern Domain defined based on local tropograhy used for later analysis are also shown

changes in convective stability in terms of the vertical profiles of moist static energy in the two regions will be discuss in Sect. 3.4. The aforementioned features indicate strong aerosol-monsoon interactions associated with advection of aerosols and increased precipitation downwind of the strengthening monsoon southwesterlies, consistent with EHP. The fluctuations in AOD, winds, and rainfall in the ND and SD are associated with development of westward propagating monsoon depression along the Himalayan foothills (See Sect. 3.4, for more detailed discussion). The overall aerosol radiation effects on the large-scale monsoon environment are examined next.

The RAD anomalies of upper tropospheric temperature and winds (Fig. 7a) shows clearly a warmer upper troposphere over northern India and regions further north with increased upper level easterlies are found near $18-25^{\circ} \mathrm{N}$ induced by ARI. The upper level anomalies are coupled to a strengthened low-level monsoon southwesterlies and a pronounced increase in moisture over northwest and northern India (Fig. 7b). Reduced moisture associated with the dry air masses and desert dust transport is found over the 
(a) 7-day Forecast (North)

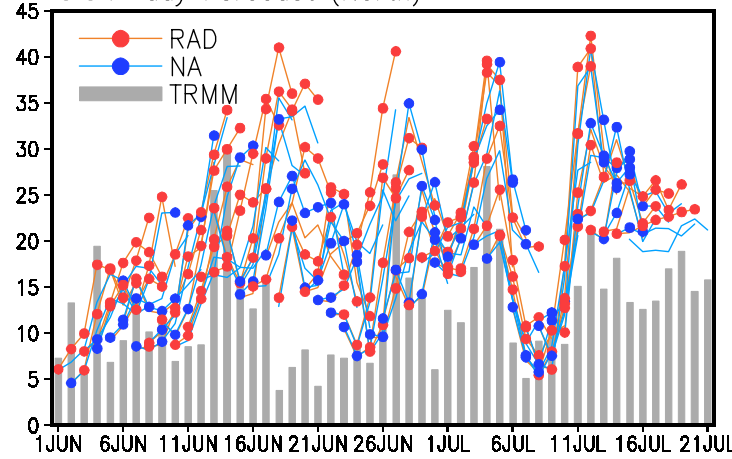

(b) F5d-F7d Mean (North)

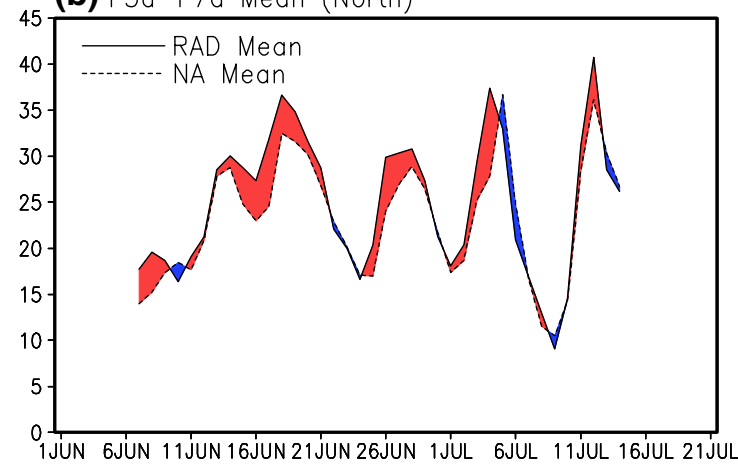

Fig. 5 Time series of a individual 7-day rainfall forecasts June 10-July 21 and b ensemble mean of Day 5-Day 7 forecasts for the Northern Domain, and same for $\mathbf{c}$ and $\mathbf{d}$ except for the Southern Domain (See domain definition in Fig. 4b). Histogram in a and c

(a)\% change in ensemble mean rainfall (shading) \& $A O D$ (contour) (80E-90E)

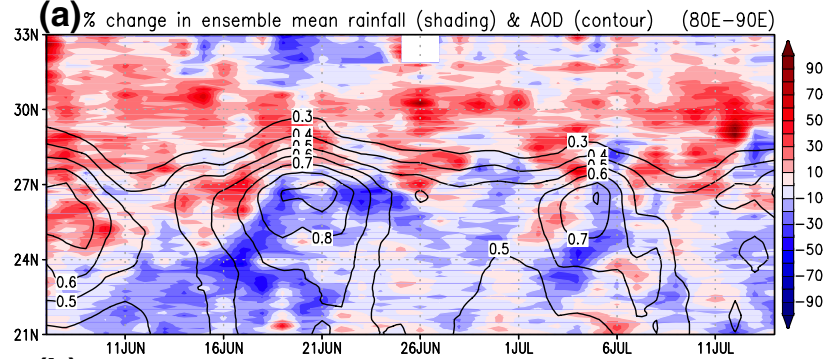

(b) Zonal (shading) \& Meridional (contour) winds at $850 \mathrm{hPa}$

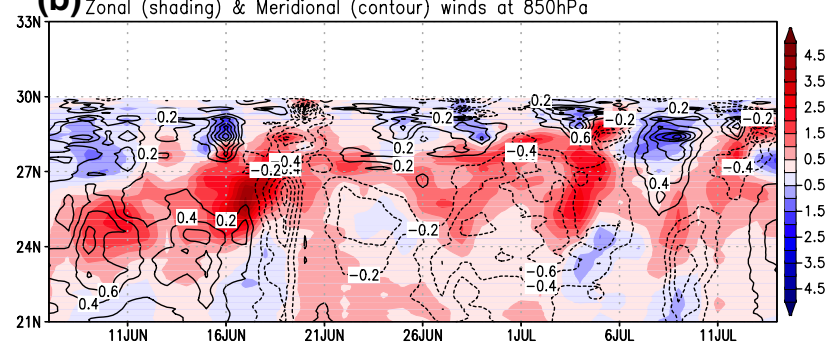

Fig. 6 Latitude-time cross-section of ensemble mean forecasts during June 1-17, 2008 for a AOD (contour) and rainfall anomalies (in $\%$ change), and $\mathbf{b}$ zonal wind (shaded) and meridional wind (contour). Unit of wind in $\mathrm{ms}^{-1}$

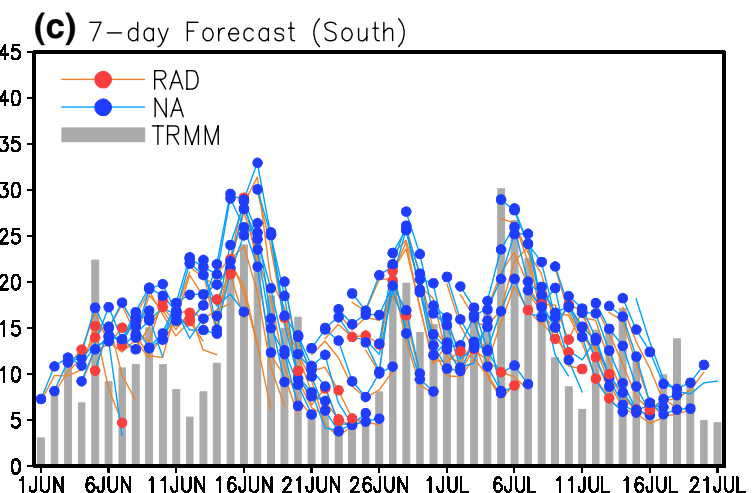

(d) F5d-F7d Mean (South)

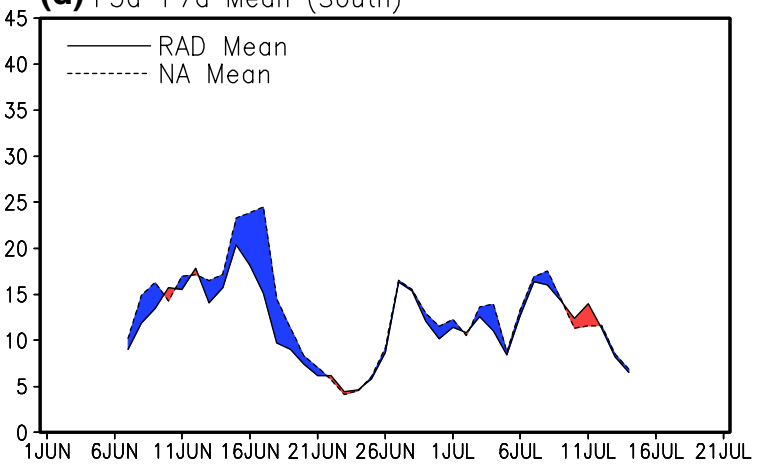

indicates observed TRMM rainfall in the Northern Domain and the Southern domain respectively. Red (blue) dots and shading indicate enhanced (reduced) rainfall in RAD relative to NA. Unit of rainfall in mmday $^{-1}$

central Arabian Sea, and northeastern India. Except for the magnitude, the anomaly patterns are quite similar to those shown in Fig. 2a, b. As stated previously, SST effects are already included in the prescribed observed SST. The present experiments are focused only on the fast responses of aerosol-monsoon dynamic interaction. The results here suggest that ARI reinforces, and adds regional details to, the SST forcing.

Additional regional features induced by aerosol radiative effects are depicted in meridional-height anomaly cross-sections (Fig. 8). Over the Arabia Sea (60-70E), the dust aerosol layer is thick, extending from the surface to $600 \mathrm{hPa}$, with maximum concentration in the $800-700 \mathrm{hPa}$ layer (Fig. 8a). Pronounced atmospheric warming is found within the dust layer, and cooling near the top of the dust layer mainly due to longwave radiation effects (Zhang and Christopher 2003; Zhu et al. 2007; Lau et al. 2009). Substantial anomalous warming is found over the upper troposphere 300-200 hPA layer, in conjunction with the enhancement of the South Asian High and associated easterly warm advection (Fig. 7a). Surface cooling is found 

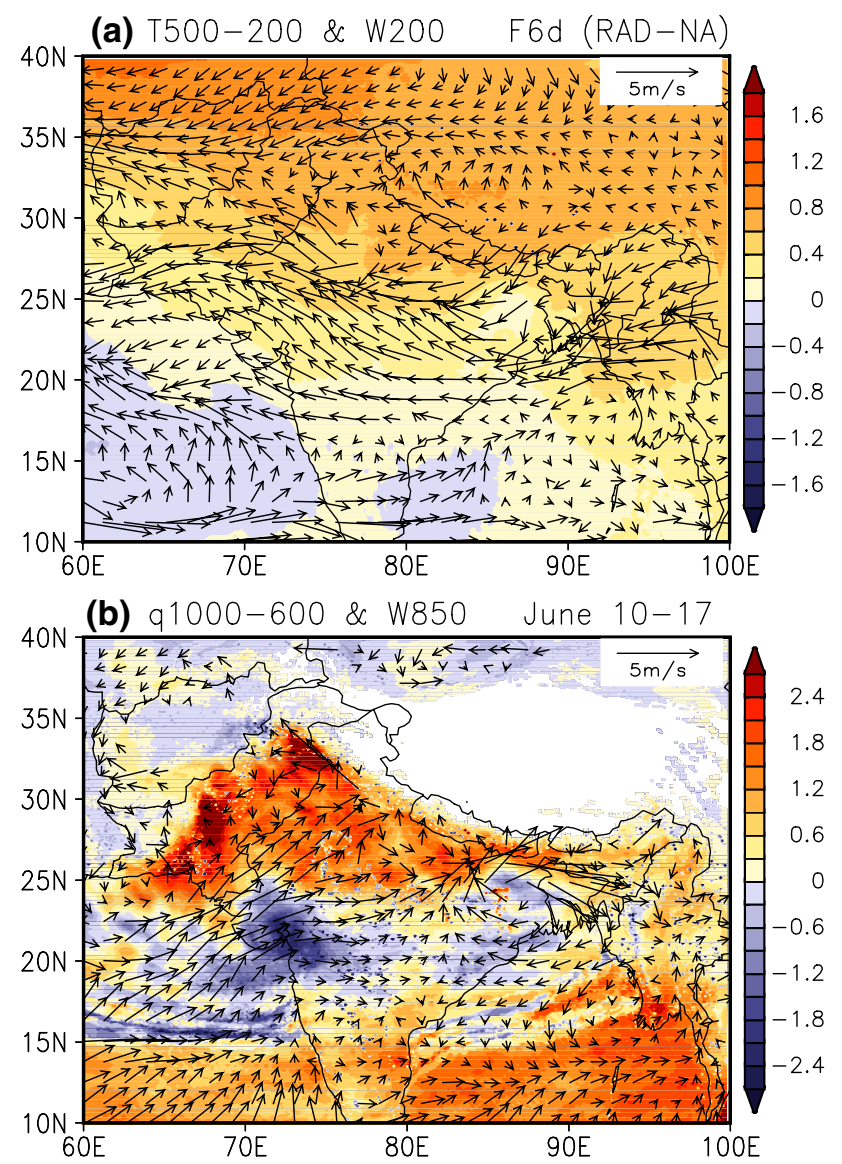

Fig. 7 Horizontal distribution of RAD anomalies in a temperature averaged between 500-200 hPa and $200 \mathrm{hPa}$ winds, and b lower tropospheric moisture and winds during June 10-17, 2008

over land surface north of $25^{\circ} \mathrm{N}$, reflecting solar attenuation effects due to aerosols (Ramanathan et al. 2005). The differential warming/cooling in the vertical increases stability in the lower troposphere, but enhances instability above, giving rise to weak rising motion in the mid- troposphere (Fig. 8c). As a result, except near the center of dust layer, the atmosphere over the Arabian Sea is generally moister (Fig. 8b). Given that the same sea surface temperature is prescribed in all experiments, the source of moisture is likely due to enhanced surface evaporation from the strengthened surface westerlies over the Arabian Sea, as well as from increased mixing of the moist marine cloud water with environmental air. Wind anomalies show increased easterlies (westerlies) in the upper (lower) troposphere indicating a strengthening of the large-scale monsoon flow. The colocation of low-level westerlies with regions of maximum aerosol loading and dry air masses signals strong westward advection of dust aerosols. As a result of the aforementioned stability changes induced by ARI, an anomalous meridional circulation with northward onshore flow towards southern Pakistan, and largely mid-tropospheric weak rising motion is found over the region. This anomalous rising motion is likely to enhance convective mixing and further moistening of the atmosphere over the ocean. However, the region remains dry in the absolute sense, with no precipitation (Fig. 8d). Over the western Indian region $\left(70^{\circ}-80^{\circ} \mathrm{E}\right)$, the aerosol-monsoon characteristics are similar to those over the Arabian Sea except that the signals are stronger, including a clear northward shift of the center of moderate precipitation, accompanying a strengthening of the local monsoonal meridional circulation (Fig. S2).

The ARI effects on precipitation and circulation are strongest over the domain covering eastern India and the western Bay of Bengal $\left(80^{\circ}-90^{\circ} \mathrm{E}\right)$. As shown in Fig. 8e, the ARI-induced upper tropospheric warming over the Tibetan Plateau and regions to the south are very pronounced. This occurs in conjunction with a pronounced elevated thick aerosol layer, pushing against the southern slopes of the Tibetan Plateau by the increasing monsoon southerlies (See Fig. 6b). Here the dust loading is lower compared to that over the Arabian Sea and western India, due to removal by both dry and wet depositions during the long-distance transport from the Middle East deserts to eastern India. However, still noticeable are the cooling near the top of the dust layer, warming within and below the dust layer and near the surface, characteristic of lightabsorbing dust layers (Zhu et al. 2007; Lau et al. 2009). A signal of the aerosol semi-direct effect reducing convective potential, in the form of strong surface cooling due to aerosol solar attenuation and warming induced by aerosol heating can be found over the $\mathrm{HF}\left(25-35^{\circ} \mathrm{N}\right.$, Fig. 8e). However, this effect is overpowered by the increased low-level moisture advection into this region by the strengthened southwesterlies, as evident in the increased moist static energy in the lower troposphere $(700 \mathrm{hPa})$ relative to the regions above (See discussion in Sect. 3.4, Fig. 11). Except within the dust layer, specific humidity is substantially increased over the entire atmospheric column. The increase is most pronounced and coincides with a strong low-level westerly jet near 25-30N, (Fig. 8f). Coupled to the wind, temperature, moisture and aerosol anomalies, is an enhanced local meridional circulation, with strong rising motion in the HF, and sinking motion to the south (Fig. 8g), and the northward displacement of the maximum rainfall over the $\mathrm{HF}$ (Fig. 8h).

\subsection{Mesoscale Interactions}

In this section, we present results on the mesoscale aspects of aerosol-monsoon interactions including both ARI and ACI effects, based on comparisons of the RADM, RAD and NA experiments. Here, we focus on the evolution of mesoscale development of monsoon rainfall systems during 
(a) Temp \& AOT

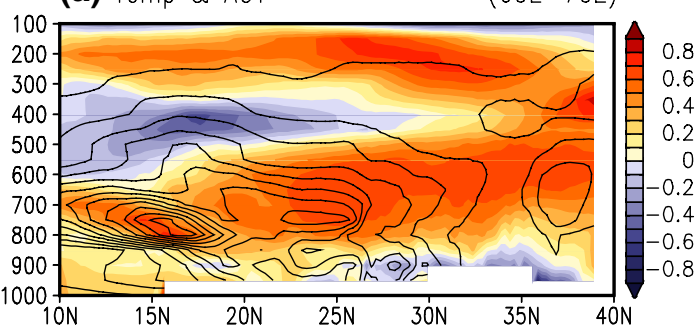

(b) Specific Humidity $(\mathrm{g} / \mathrm{Kg})$

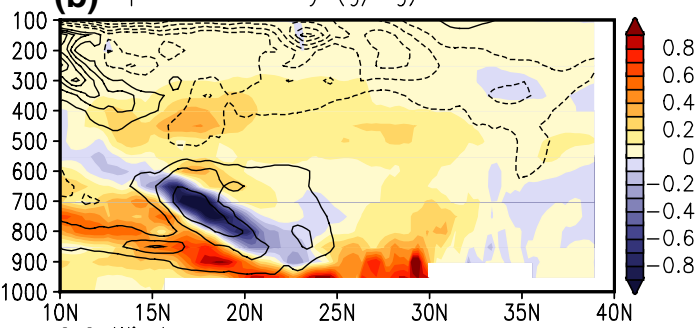

(c) Winds

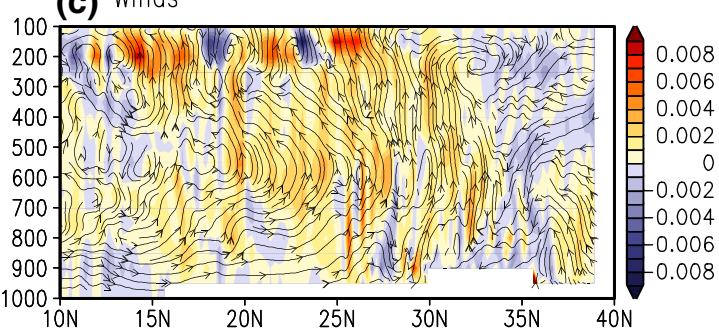

(d) Precipitation

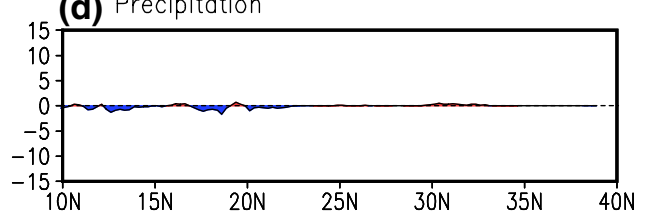

Fig. 8 Height-latitude cross sections of a temperature (color shaded) and AOT (contoured), b specific humidity (color shaded) and zonal wind (contoured), c meridional streamlines with vertical upward (downward) motions shaded red (blue), and d precipitation anomalies

the onset phase (June 11-17) of the 2008 Indian monsoon. As shown in Fig. 9 (panels in left column), in the absence of aerosol effects (NA), the onset of the Indian monsoon over northern India was associated with increased transport of moisture to the NIHF regions by the increasing monsoon southwesterlies, resulting in the spontaneous development of a monsoon depression (cyclonic circulation cell) over the northern Bay of Bengal as shown in the NA Day-4 forecast. At Day-5, a secondary cyclone was spurred over the northern-central IGP. Subsequently, both monsoon cyclones amplified and propagated northwestward, over the IGP. Such evolution of monsoon depressions is well known during the monsoon onset, and active phases of the monsoon over northern India (Krishnamurti and Bhalme 1976; Saha et al. 1981). In RAD (panels in middle column), the effect of ARI noticeable starting around Day-5, in a weakening of the primary monsoon depression compared to NA, and (e) Temp \& AOT

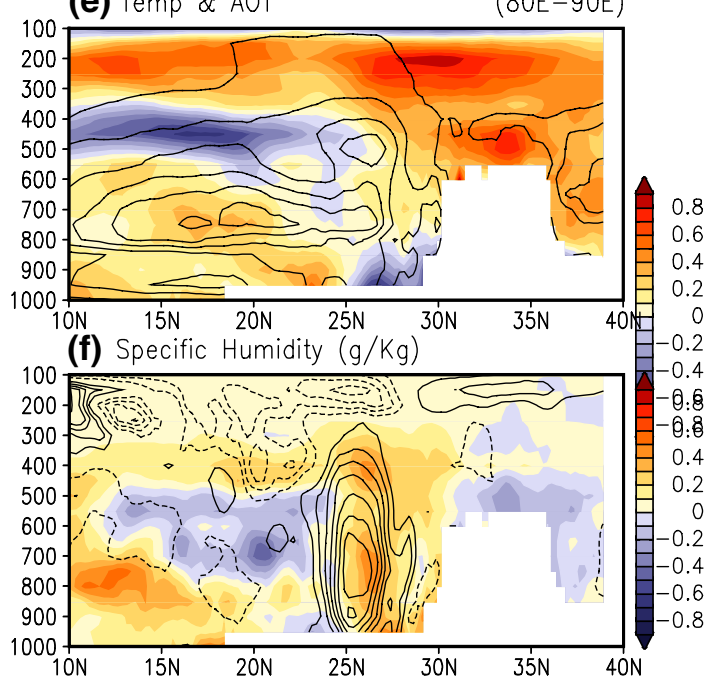

(g) Winds

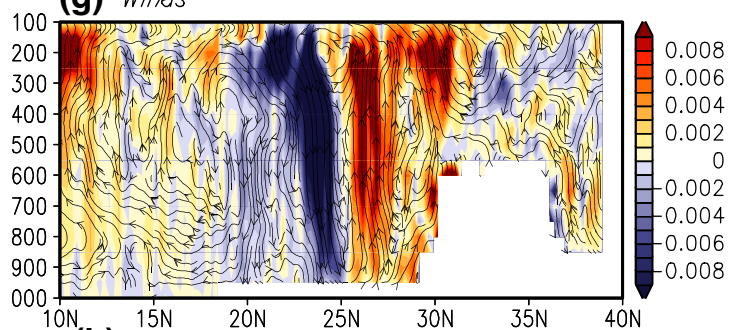

(h) Precipitation

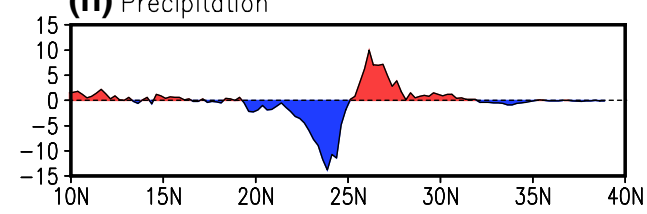

for the Arabian Sea-Pakistan-Afghanistan region (60-70E). Positive (negative) anomalies are indicated by solid (dashed) contours, or red (blue) color. Same for $\mathbf{e}, \mathbf{f}, \mathbf{g}$ and $\mathbf{h}$, except for the northern and northeastern India sector $80-90^{\circ} \mathrm{E}$

in the development of intense small-scale convection cells further northwestward up the HF. The suppression of the primary monsoon depression, and the development of vigorous convective cells along the HF continue, with the most pronounced signal at Day-7. In RADM (panels in right column), the inclusion of ACI further enhances the ARI effects (See discussions related to Figs. 10, 11). The suppression of the primary monsoon onset cyclone is already noticeable at Day-4, and the subsequent transformation (Day-5 to Day-7) of the monsoon onset cyclones (in NA) is similar to ARI effects, except with faster speed, increased intensity and with more numerous convective cells. The metamorphosis of the monsoon depression in NA to invigorated line precipitation cells along the HF, due to combined effects of ARI and ACI is most striking at forecast Day-7.

The invigoration of deep convection by ARI and ACI in the HF region is further examined via the vertical 

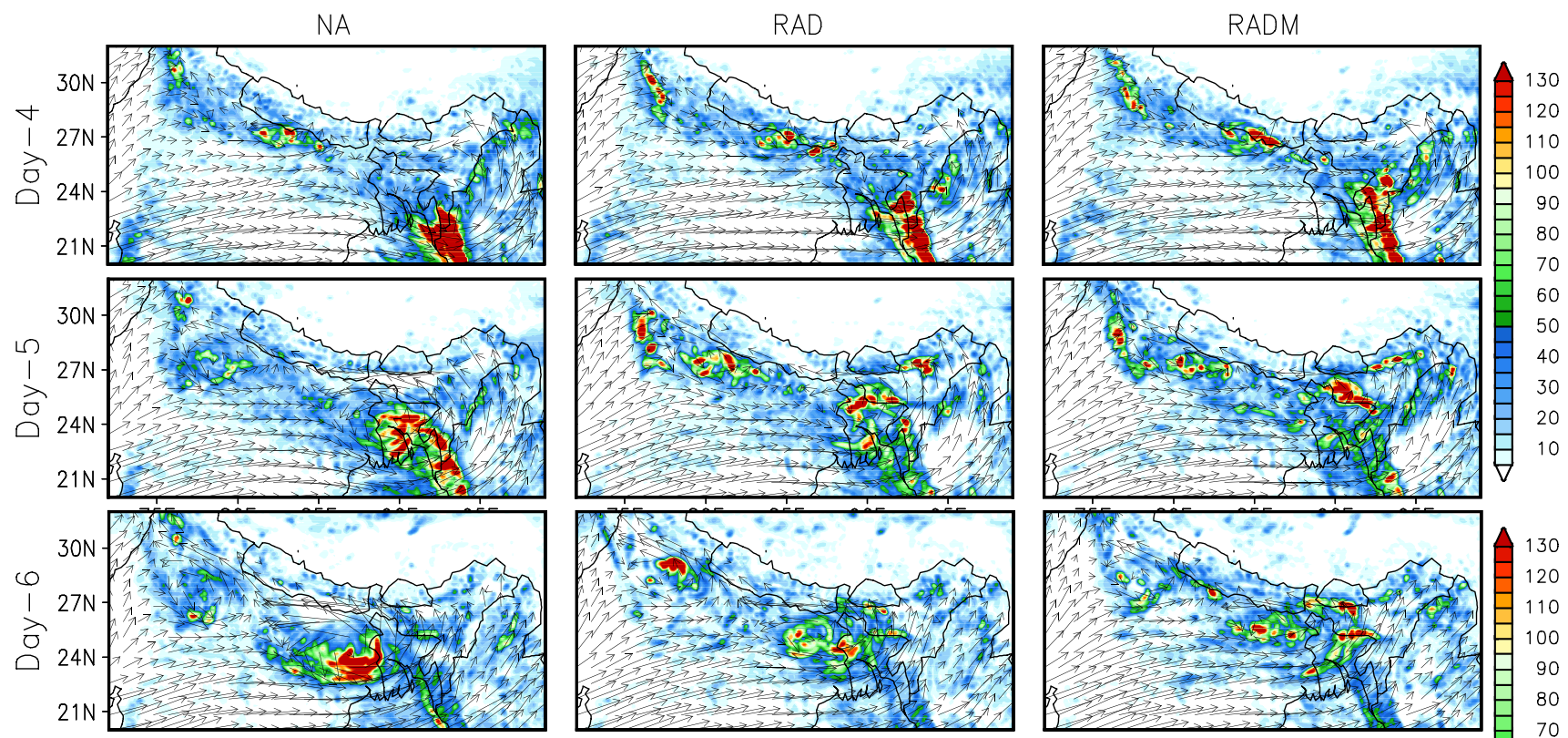

130

120
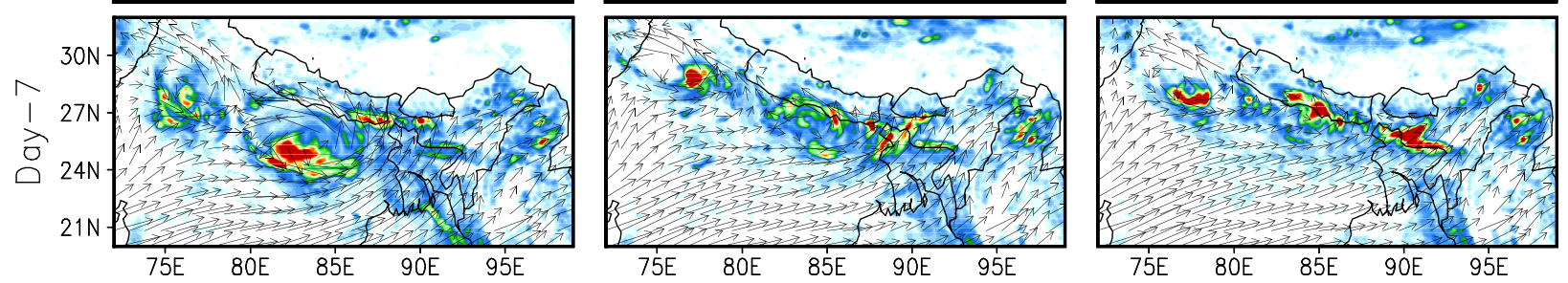

Fig. 9 Time sequence showing the genesis and evolution of monsoon rainfall and mesoscale convective complex from forecast Day 4 to Day 7 , for a NA, b RAD and $\mathbf{c}$ RADM. Extreme heavy precipitation $\left(>120 \mathrm{~mm} \mathrm{day}^{-1}\right)$ is shaded red

distributions of hydrometeors associated with the deepening convection in the ND and SD. Without aerosol effects (NA), the distributions of liquid water (cloud and rain), cloud ice, snow and graupel indicate stronger development of deep convection in SD than in ND (Fig. 10a, b). Comparing RAD (Fig. 10c, d) with NA (Fig. 10a, b), ARI shifts the maximum cloud ice upwards from 250 to $200 \mathrm{hPa}$, enhances the concentration of snow and graupel in the 500-300 hPa layer, and increases liquid water content in the lower troposphere in the ND. In the SD, the effects are reversed, with substantial reduction in deep convection as evidenced in substantial loss of cloud ice, and snow and graupel in the mid to upper troposphere, as well as suppressed cloud and rain water in the lower troposphere. Comparing RADM (Fig. 10e, f) and RAD (Fig. 10c, d) anomalies indicates that deep convection is further enhanced by $\mathrm{ACI}$ in $\mathrm{ND}$, as evident in the larger magnitude and extent of the increase in cloud ice, and snow/graupel in the mid- and upper troposphere. This appears to be at the expense of reduced rate of increase in cloud and rain water in the lower troposphere compared to RAD. In the SD, the stronger reduction hydrometeors of all kinds suggest a further suppression of deep convection by ACI. For the domain as a whole, the change in total rainfall due to inclusion of ACI is relatively small $(<5 \%)$. Most of the changes by ACI appear to be in the nature of the deep convection and not in the total rain. These results are consistent with modeling and observations indicating enhanced glaciation, and formation of deeper clouds by aerosols in a moist environment [Rosenfeld et al. 2008; Fan et al. 2013].

The changes in the nature of the deep convection induced by ARI and ACI can be viewed in terms of changes in moist static energy (MSE) of the atmosphere over the ND and SD during the onset phase (Fig. 11). Judging from the stronger negative gradient (reduction with height) in mean MSE in the lower troposphere (Fig. 11a, b), it can be inferred that in the absence of aerosol influence (NA), the SD is more (compared to the ND) convectively unstable, and convection is likely to be deeper, as reflected in the larger loading of hydrometeors of all types (Fig. 10a, b). Under ARI forcing, the lower troposphere in ND (Fig. 11c, d) is further destabilized with increase in negative gradient MSE between $800 \mathrm{hPa}$ and $600 \mathrm{hPa}$, while the mid- to upper troposphere between 600 and $300 \mathrm{hPa}$ are stabilized, as evidence in the positive gradients in MSE between these two levels. Above $300 \mathrm{hPa}$, the MSE reflects again a 

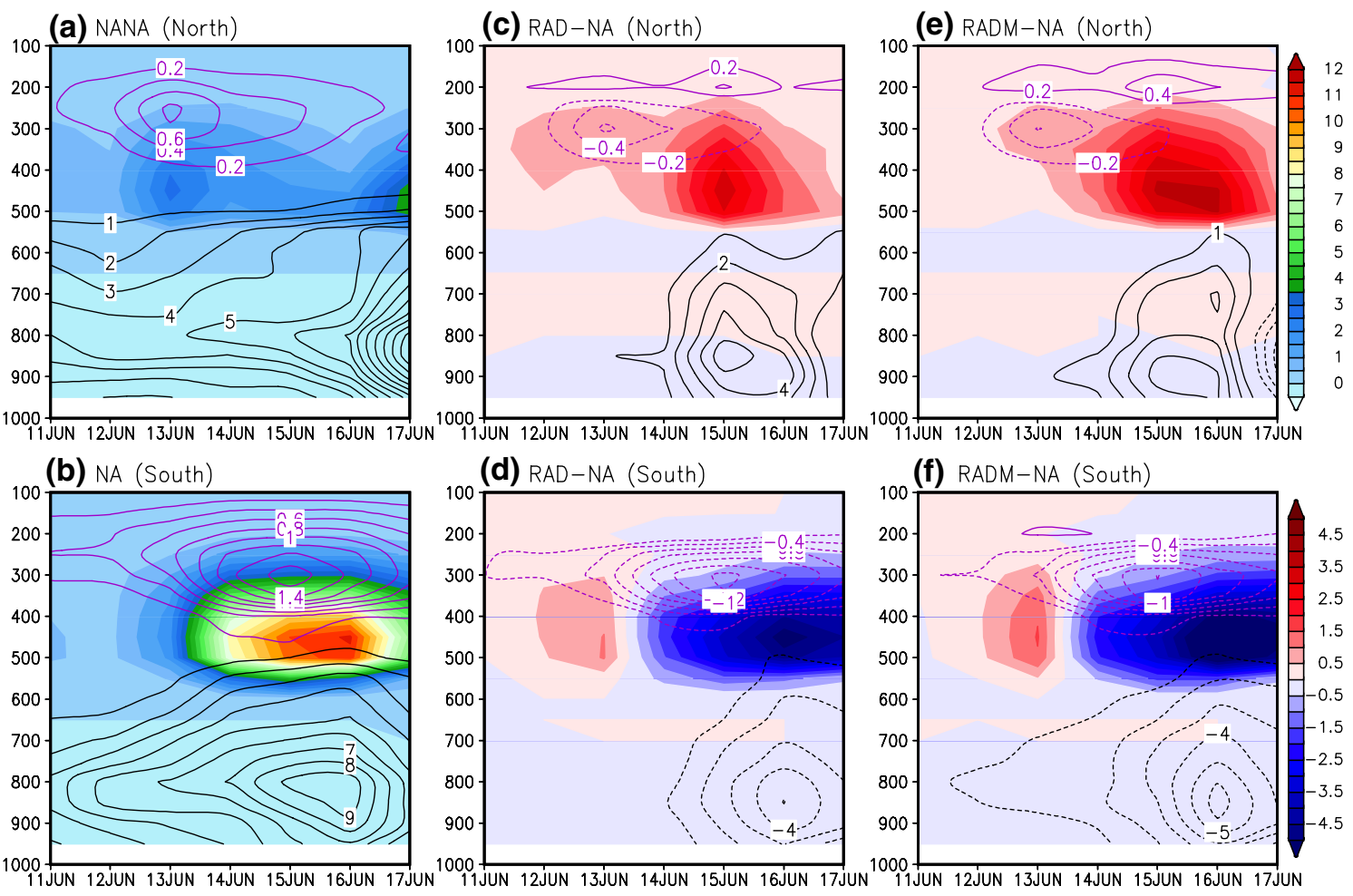

Fig. 10 Time-height distribution of different hydrometeor species for $\mathbf{a}$ the Northern Domain in NA, and $\mathbf{b}$ the Southern Domain in NA. Same for $\mathbf{c}$ and $\mathbf{d}$, except for the RAD anomalies, and same for $\mathbf{e}$ and f, except for RADM anomalies. Purple contour, color shading, and black contour denotes respectively concentration of cloud-ice, snow and graupel, and liquid phase clouds and rain. Positive (negative) anomalies in $\mathbf{c}$ through $\mathbf{f}$ are indicated either by solid (dashed) contours or red (blue) shading. Units are in $10^{-5} \mathrm{~kg} \mathrm{~m}^{-3}$ convective de-stabilization of the atmosphere. Computations of separate contributions to the MSE (Fig. S3) shows that the destabilization in the lower troposphere is mainly due to increased moisture, while stabilization is mainly due to temperature change, i.e., aerosol semi-direct effect in heating the lower troposphere and cooling of the surface. Changes in MSE in the mid-to upper troposphere is associated with temperature change due to moist adiabatic ascent of heated air from below reaching maximum altitude. Essentially, in the ND, the low-level moisture effect overpowers the aerosol semi-effect, invigorating more intense convection and rainfall. Clearly, ACI enhances the MSE convective stability modulation due to ARI, favoring enhanced deep convection in ND (Fig. 11e). In contrast, for the SD under ARI (Fig. 11f), both the aerosol semi-direct effect and the reduction in moisture by advection (see discussion related to Fig. 7) stabilizes the lower troposphere, leading to the dissipation of the monsoon depression and suppressed precipitation. This effect is further amplified by ACI (Fig. 11f). As noted previously, the northward advection of the un-precipitated moisture from suppressed rainfall in SD by the strengthened southerlies can further increase in convective instability and rainfall in ND. This is the essence of the EHP effect. Overall, it can be argued that the MSE changes provide the physical underpinnings of anomalous deep convection, rainfall and moisture transport induced by ARI and ACI in the NIHF region.

\section{Conclusions}

Using the NU-WRF model, we have conducted numerical forecast experiments to investigate the dynamics of aerosol-monsoon interaction over the complex topography of the NIHF region, under realistic initial and boundary conditions. Results show that aerosol-monsoon interactions have strong impacts on regional monsoon rainfall and circulation during the onset phase of 2008 Indian monsoon, consistent with the EHP hypothesis. Key findings include:

- The complex and steep topography of the Himalaya foothills facilitate the build up of thick layers of dust aerosols transported by monsoon southwesterlies from the Arabian Peninsular deserts across the Arabian Sea, and accumulated over northwestern and central India during the pre- and early monsoon season of 2008. 

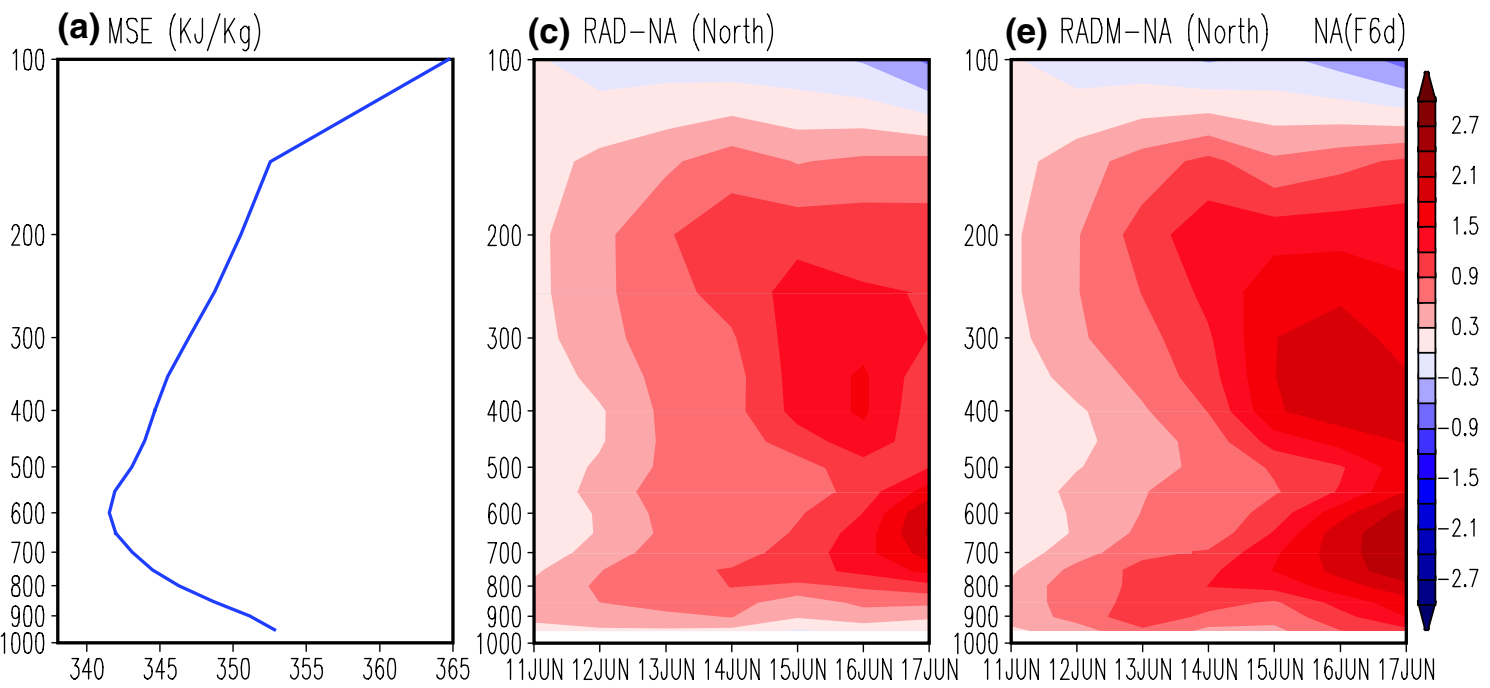

(b) MSE $(\mathrm{KJ} / \mathrm{Kg})$

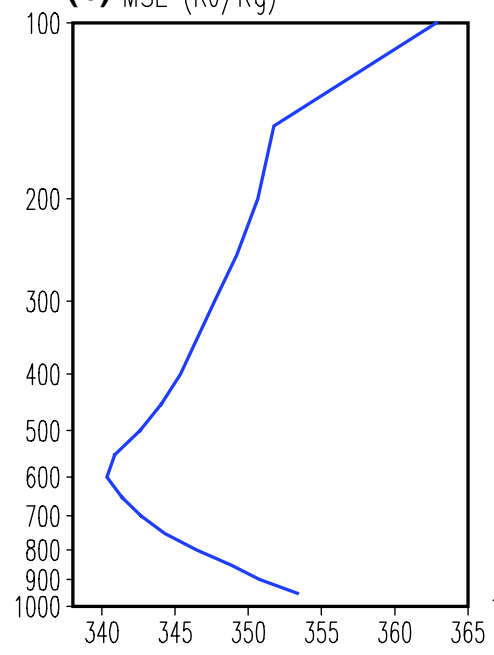

(d) RAD-NA (South)
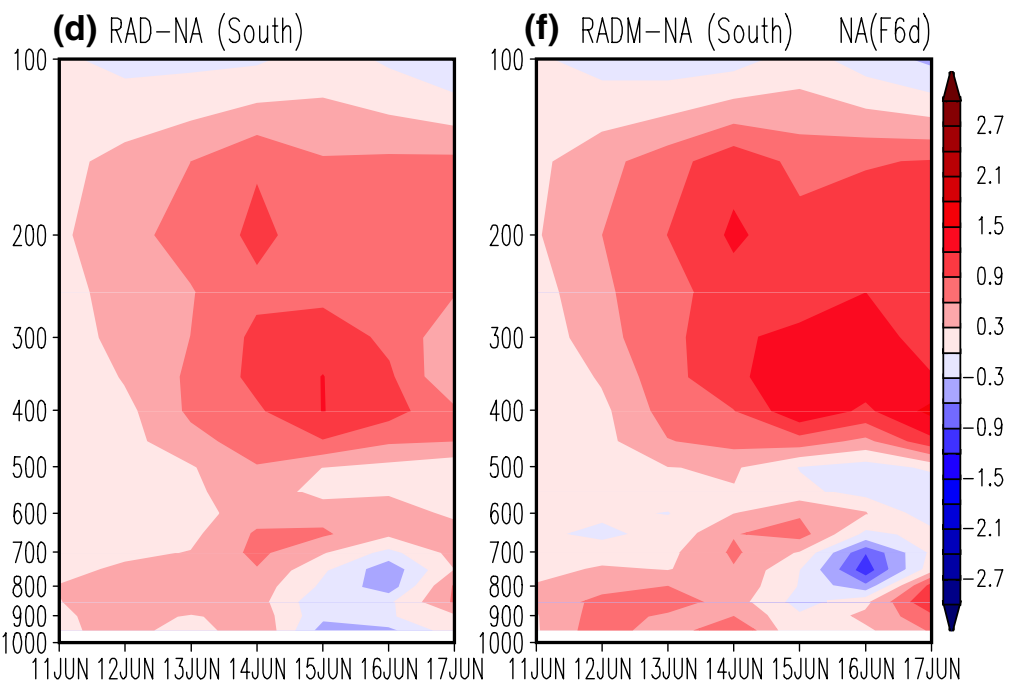

Fig. 11 Vertical profile of MSE $\left(\mathrm{KJ} \mathrm{Kg}^{-1}\right)$ showing a mean distribution for the Northern Domain and $\mathbf{b}$ the Southern Domain. Same for $\mathbf{c}$ and $\mathbf{d}$ except for RAD anomalies for forecast Day 6, and $\mathbf{e}$ and $\mathbf{f}$ except for RADM anomalies for forecast Day 6

- Via aerosol induced dynamical feedback, ARI warms the upper troposphere over the Tibetan Plateau, increases the mid-to-upper tropospheric north-south temperature gradient, and thus strengthens the early Indian monsoon by shifting maximum monsoon rainfall from the Indo-Gangetic Plain to the Himalayan foothills regions, and advancing the timing of monsoon onset over HF by $1-5$ days.

- Aerosols have both local and non-local effects, which interacts with each other. Generally, regions of high aerosol loading are associated with drier air masses and suppressed rainfall, and heavy rain regions with low aerosol loading due to wash-out. The semi-direct (local) effect of dust aerosols leads to the stabilization and weakening of a developing monsoon depression over northeastern India and northern Bay of Bengal during the onset phase of the monsoon.
- Non-local effects are exerted mainly through moisture and circulation feedback. Heating by thick dust layer over the Arabian Sea and northern India, enhances the large-scale southwesterly low-level monsoon flow and transport of moisture from the Arabian Sea to the Indian subcontinent. The enhanced southwesterly moisture transport increases low-level MSE, leading to the development of intense convective cells over the Himalaya Foothill regions.

- While ARI dominates the large-scale aerosol-monsoon interaction, ACI further enhances the ARI effects, by suppressing development of monsoon depression over northeastern India, while intensifying the ice-phase precipitation and deep cloud processes in the HF, and thereby speeding up the transformation the monsoon depression into intense meso-scale cells with heavy rain in the forms line convection along the rugged terrains of the HF. 
Our results are in general agreement with recent modeling studies using the WRF-CHEM. Krishnamurti et al. (2013) showed that the development of monsoon depression is suppressed by aerosol via increased cloud condensation nuclei (CNN), over northeastern India and Bay of Bengal. However, their results did not indicate development of mesoscale-scale deep convection over the Himalayan foothills, most likely because aerosol number concentration was prescribed in their experiments, which therefore did not include the full interactions of aerosol radiation, microphysics, and removal processes, with monsoon dynamics. Jin et al. (2015) using WRF-CHEM and satellite observations also found that the influx of Middle East dust, mainly through radiative forcing, could redistribute and increase Indian summer monsoon regional rainfall, consistent with our results. However the relative low resolution model $(\sim 35 \mathrm{~km})$ they used would be unable to resolve the aerosol-monsoon dynamic interaction over the complex topography of Himalayas regions. Moreover, they focused on the mean response of the entire Indian monsoon season (June-August), while we emphasize the short-term ( $<7$ days) interactions during the onset phase of the monsoon. We also note that, even with the 9-km resolution used our experiments, the resolution is still relative coarse, in terms of realistic representation of aerosol-cloud microphysics. Cloud resolving scales $(<2-3 \mathrm{~km})$ is highly desirable for better representation the interaction of aerosol with the complex topography of the Himalaya foothills. However, for such high resolution simulation, only short-term integrations, with single or few ensemble simulations are feasible, because of the prohibitive computational demands. Furthermore, as noted in the discussion in Sect. 3.2, while NUWRF simulated the AOD spatial distribution reasonably well, the magnitude of the aerosol loading was significantly underestimated, compared to MODIS observation. Assuming that a heavier aerosol loading will produce stronger impacts on monsoon, it is plausible that the present results may have underestimated the actual impacts of aerosols in reality.

As a caveat, we note that our results are based on a singular monsoon year of 2008. More studies need to be carried out to ascertain the robustness of the results. Nonetheless, the fundamental physical processes revealed by this study, together with many recent studies of aerosol impacts on monsoon weather and climate, lend support to the paradigm that aerosol from natural sources is an essential components of the Asian monsoon climate, affecting variability of the monsoon on diverse spatio-temporal scales (Lau 2016).

Finally, an important message from our study, consistent with many contemporary studies on aerosol-monsoon interactions (See Li et al. 2016 for a comprehensive review), is that aerosol-monsoon interaction is important not only for climate change but also for short-term weather (3-7 days) forecasts, and very likely for medium to long-term forecasts ( $>7$ days) as well as seasonal-to-interannual predictions of the Asian monsoon.

Acknowledgements This work is partially supported by the NASA Precipitating Measuring Mission (PMM) Program, the NUWRF project under NASA Modeling and Analysis and Prediction Program (MAP), and the Department of Energy/ Pacific Northwest National Laboratory Grant 4313671 to ESSIC, University of Maryland.

Open Access This article is distributed under the terms of the Creative Commons Attribution 4.0 International License (http://creativecommons.org/licenses/by/4.0/), which permits unrestricted use, distribution, and reproduction in any medium, provided you give appropriate credit to the original author(s) and the source, provide a link to the Creative Commons license, and indicate if changes were made.

\section{References}

Andreae MO, Rosenfeld D (2008) Aerosol-cloud-precipitation interactions. Part 1. The nature and sources of cloud-active aerosols. Earth Sci Rev 89:13-41

Bosilovich $M$ et al (2015) MERRA-2: initial evaluation of the climate. In: Koster R (ed) Technical Report Series on Global Modeling and Data Assimilation. NASA/TM-2015-104606/Vol.43

Barros AP, Lang TJ (2003) Monitoring the monsoon in the Himalayas: observations in Central Nepal, June 2001. Mon Weather Rev 131:1408-1427

Barros AP, Lattenmaier DP (1994) Dynamic modeling of orographically induced precipitation. Rev Geophys 32:265-284

Boos W, Kuang Z (2010) Dominant control of the South Asian monsoon by orographic insulation versus plateau heating. Nature 463:218-222. doi:10.1038/nature08707

Chin M, Chu DA, Levy R, Remer L, Kaufman Y, Holben B, Eck T, Ginoux P, Gao Q (2004) Aerosol distribution in the Northern Hemisphere during ACE-Asia: results from global model, satellite observations, and Sun photometer measurements. J Geophys Res 109:D23S90. doi:10.1029/2004GL02014

Chin M, Diehl T, Dubovik O, Eck TF, Holben BN, Sinyuk A, Streets DG (2009) Light absorption by pollution, dust and biomass burning aerosols: a global model study and evaluation with AERONET data. Ann Geophys 27:3439-3464

Chin M, Diehl T, Tan Q, Prospero JM, Kahn RA, Remer LA, Yu H, Sayer AM, Bian H, Geogdzhayev IV, Holben BN, Howell SG, Huebert BJ, Hsu NC, Kim D, Kucsera TL, Levy RC, Mishchenko MI, Pan X, Quinn PK, Schuster GL, Streets DG, Strode SA, Torres O, Zhao X-P (2014) Multi-decadal variations of atmospheric aerosols from 1980 to 2009: a perspective from observations and a global model. Atmos Chem Phys 14:3657-3690

Collier JC, Zhang GJ (2009) Aerosol direct forcing of the summer Indian monsoon as simulated by the NCAR CAM3. Clim Dyn 32:313. doi:10.1007/s00382-008-0464-9

D'Errico M, Cagnazzo C, Gogli PG et al (2015) Indian monsoon and the elevated-heat pump mechanism in a coupled aerosol-climate model. J Geophys Res 120:8712-8723. doi:10.1002/2015JD023346

Das S, Mohanty UC, Tyagi A, Sikka DR, Joseph PV, Rathore LS, Habib A, Baidya SK, Snam K, Sarkar A (2014) The SAARC STORM: a coordinated filed experiment on severe thunderstorm observations and regional modeling over the South Asian region. Bull Am Meteorol Soc. doi:10.1175/BAMS-D-12-00237.1

Demott PJ, Prenni AJ, Liu X, Kreidenweis SM, Petters MD, Twohy CH, Richardson MS, Eidhammer T, Rogers DC (2010) 
Predicting global atmospheric ice nuclei distributions and their impacts on climate. Proc Natl Acad Sci 107(25):11217-11222

Eck TF et al (2010) Climatological aspects of the optical properties of fine/coarse mode aerosol mixtures. J Geophys Res 115:D19205. doi:10.1029/2010JD014002

Fan J, Leung LR, Rosenfeld D, Chen Q, Li Z, Zhang J, Yan H (2013) Microphysical effects determine macrophysical response for aerosol impacts on deep convective clouds. Proc Natl Acad Sci USA 110:E4581-E4590. doi:10.1073/pnas.1316830110

Gadgil S et al (2003) The Indian monsoon and its variability precipitation fluctuations in the Nepal Himalaya and its vicinity and relationship with some large-scale climatological parameters. Annu Rev Earth Planet Sci 31:429-467

Ganguly D, Gadhavi H, Jayaraman A, Rajesh TA, Misra A (2005) Single scattering albedo of aerosols over the central India: implications for the regional aerosol radiative forcing. Geophys Res Lett. doi:10.1029/2005GL023903

Gillette DA, Passi R (1988) Modeling dust emission caused by wind eroson. J Geophys Res 93:14233-14242

Ginoux P, Chin M, Tegen I, Prospero JM, Holben B, Dubovik O, Lin S-J (2001) Sources and distributions of dust aerosols simulated with the GOCART model. J Geophys Res 106(D17):2025520273. doi: $10.1029 / 2000 J D 000053$

Goswami BN, Xavier PK (2005) ENSO control on the south Asian monsoon through the length of the rainy season. Geophys Res Lett 32:L18717. doi:10.1029/2005GL023216

Hazra A, Goswami BN, Chen Jen-Ping (2013) Role of interactions between aerosol radiative effect, dynamics, and cloud microphysics on transitions of monsoon intraseasonal oscillations. J Atmos Sci 70:2073-2087. doi:10.1175/JAS-D-12-0179.1

Henriksson SV, Pietikäinen J-P, Hyvärinen A-P, Räisänen P, Kupiainen K, Tonttila J, Hooda R, Lihavainen H, O'Donnell D, Backman L, Klimont Z, Laaksonen A (2014) Spatial distributions and seasonal cycles of aerosol climate effects in India seen in a global climate-aerosol model. Atmos Chem Phys 14:1017710192. www.atmos-chem-phys.net/14/10177/2014/ doi:10.5194/ acp-14-10177-2014

Houze RA, Wilton DC, Smull BF (2007) Monsoon convection in the Himalayan region as seen by the TRMM precipitation radar. Q J R Meteorol Soc 133:1389-1411. doi:10.1002/qj.106

Jin Q, Weil J, Yang ZL, Pu B, Huang J (2015) Consistent response of Indian summer monsoon to Middle East dust in observations and simulations. Atmos Chem Phys 15:9897-9915. doi:10.5194/ acp-15-9897-2015

Kim M-K, Lau WK-M, Kim K-M et al (2015) Amplification of ENSO effects on Indian summer monsoon by absorbing aerosols. Clim Dyn. doi:10.1007/s00382-015-2722-y

Koehler KA, Kreidenweis SM, DeMott PJ, Prenni AJ, Carrico CM, Ervens B, Feingold G (2006) Water activity and activation diameters from hygroscopicity data-part II: application to organic species. Atmos Chem Phys 6:795-809

Krishnamurti TN, Bhalme H (1976) Oscillations of a monsoon system. Part I: observational aspects. J Atmos Sci 33:1937-1954

Krishnamurti TN, Xue J, Bedi HS, Ingles K, Oosterhof D (1991) Physical initialization for numerical weather prediction over the tropics. Tellus B 43:53-81. doi:10.1034/j.1600-0889.1991.t01-2-00007.x

Krishnamurti TN, Martin A, Krishnamurti R, Simon A, Thomas A, Kumar V (2013) Impacts of enhanced CCN on the organization of convection and recent reduced counts of monsoon depressions. Clim Dyn 41:117-134. doi:10.1007/s00382-012-1638-z

Lang S, Tao W-K, Chern J-D, Wu D, Li X (2014) Benefits of a 4th ice class in the simulated radar reflectivities of convective systems using a bulk microphysics scheme. J Atmos Sci 71:3583-3612

Lau WKM (2014) Desert dust and monsoon rainfall. Nat Geosci. doi:10.1038/ngeo2115
Lau WKM (2016) The aerosol-monsoon climate system of Asia: a new paradigm. J Meteorol Res. doi:10.1007/s13351-015-5999-1

Lau KM, Kim KM (2006) Observational relationships between aerosol and Asian monsoon rainfall, and circulation. Geophys Res Lett 33:L21810. doi:10.1029/2006GL027546

Lau KM, Kim MK, Kim KM (2006) Aerosol induced anomalies in the Asian summer monsoon: the role of the Tibetan Plateau. Clim Dyn 26(7-8):855-864. doi:10.1007/s00382-006-0114-z

Lau KM, Ramanathan V, Wu G-X, Li Z, Tsay SC, Hsu C, Sikka R, Holben B, Lu D, Tartari G, Chin M, Koudelova P, Chen H, Ma Y, Huang J, Taniguchi K, Zhang R (2008) the joint aerosolmonsoon experiment: a new challenge in monsoon climate research. Bull Am Meteorol Soc 89:369-383. doi:10.1175/ BAMS-89-3-369

Lau KM, Kim KM, Sud YC, Walker GK (2009) A GCM study of the response of the atmospheric water cycle of West Africa and the Atlantic to Saharan dust radiative forcing. Ann Geophys 27:4023-4037. doi:10.51941/Angeo-27-4023-2009

Li C, Yanai M (1996) The onset and interannual variability of the Asian summer monsoon in relationship to land-sea thermal contrast. J Clim 9:358-374

Li Z, Lau WK-M, Ramanathan V, Wu G, Ding Y, Manoj MG, Liu J, Qian Y, Li J, Zhou T, Fan J, Rosenfeld D, Ming Y, Wang Y, Huang J, Wang B, Xu X, Lee S-S, Cribb M, Zhang F, Yang X, Takemura T, Wang K, Xia X, Yin Y, Zhang H, Guo J, Zhai PM, Sugimoto N, Babu SS, Brasseur GP (2016) Aerosol and monsoon climate interactions over Asia. Geophys Rev 54. doi:10.1002/2015RG00050

Liu Y, Daum PH (2004) Parameterization of the autoconversion process. Part I: analytical formulation of the Kessler-type parameterizations. J Atmos Sci 61:1539-1548

Manoj MG, Devara PCS, Safai PD (2011) Absorbing aerosols facilitate transition of Indian monsoon breaks to active spells. Clim Dyn 37:2181-2198. doi:10.1007/s00382-010-0971-3

Meehl G, Arblaster J, Collins W (2008) Effects of black carbon aerosols on the Indian monsoon. J Clim. doi:10.1175/2007JCLI1777.1

Peters-Lidard PR, Houser Y, Tian SV, Kumar J, Geiger S, Olden L, Lighty B, Doty P, Dirmeyer J, Adams K, Michell EF, Wood J Sheffield (2007) High-performance earth system modeling with NASA/GSFC's land information system (LIS). Innov Syst Softw Eng 3:157-165. doi:10.1007/s11334-007-0028-x

Peters-Lidard CD, Kemp EM, Matsui T, Santanello JA Jr, Kumar SV, Jacob JP, Clune T, Tao W-K, Chin M, Hou A, Case JL, Kim D, Kim K-M, Lau W, Liu Y, Shi J-J, Starr D, Tan Q, Tao Z, Zaitchik BF, Zavodsky B, Zhang SQ, Zupanski M (2015) Integrated modeling of aerosol, cloud, precipitation and land processes at satellite-resolved scales. Environ Model Softw 67:145-159. doi:10.1016/j.envsoft.2015.01.007

Ramanathan V, Chung C, Kim D, Bettge T, Buja L, Kiehl JT, Washington WM, Fu Q, Sikka DR, Wild M (2005) Atmospheric brown clouds: impacts on South Asian climate and hydrological cycle. Proc Natl Acad Sci USA 102:5326-5333. doi:10.1073/ pnas.0500656102

Randles CA, Ramaswamy V (2008) Absorbing aerosols over Asia: a geophysical fluid dynamics laboratory general circulation model sensitivity study of model response to aerosol optical depth and aerosol absorption. J Geophys Res. doi:10.1029/2008JD010140

Rao SA, Chaudhari HS, Pokhrel S, Goswami BN (2011) Unusual central Indian drought of summer monsoon 2008: role of Southern Tropical Ocean Warming. J Clim 23:5163-5174. doi:10.117 5/2010JCL3257.1

Rasmussen KL, Houze RA Jr (2012) A flash-flooding storm at the steep edge of high terrain: disaster in the himalayas. Bull Am Meteorol Soc 93:1713-1724

Rosenfeld D, Lohmann U, Raga GB, O'Dowd CD, Kulmala M, Fuzzi S, Reissell A, Andreae MO (2008) Flood or drought: 
how do aerosols affect precipitation? Science. doi:10.1126/ science. 1160606

Saha K, Sanders F, Shukla J (1981) Westward propagating predecessors of monsoon depressions. Mon Weather Rev 109:330-343

Sanap SD, Pandithurai G (2015) The effect of absorbing aerosols on Indian monsoon circulation and rainfall: a review. Atmos Res 164:318-327. doi:10.1016/j.atmosres.2015.06.002

Satheesh SK, Krishna Moorthy K, Suresh Babu S, Vinoj V, Dutt CBS (2008) Climate implications of large warming by elevated aerosol over India. Geophys Res Lett. doi:10.1029/2008GL034944

Shi JJ, Matsui T, Tao W-K, Peters-Lidard C, Chin M, Tan Q, Pickering K, Guy N, Lang S, Kemp E (2014) Implementation of an aerosol-cloud microphysics-radiation coupling into the NASA unified WRF: simulation results for the 6-7 August 2006 AMMA special observing period. Q J R Meteorol Soc 140:2158-2175. doi:10.1002/qj.2286

Tao W-K, Anderson D, Chern J, Estin J, Hou A, Houser P, Kakar R, Lang S, Lau W, Peters-Lidard C, Li X, Matsui T, Shen B-W, Shi J-J, Zeng X (2009) Goddard multi-scale modeling systems with unified physics. Ann Geophys 27:3055-3064

Tao Z, Santanello JA, Chin M, Zhou S, Tan Q, Kemp EM, Peters-Lidard CD (2013) Effect of land cover on atmospheric processes and air quality over the continental United States: a NASA Unified WRF (NU-WRF) model study. Atmos Chem Phys 13:6207-6226

Tyagi A, Hatwar HR, Pai DS (2009) Monsoon 2008: a report. National Climate Centre, Indian Met. Dept., Monograph, Synoptic Meterorology No: 07/2009

Vinoj V, Rasch PJ, Wang HL et al (2014) Short term modulation of Indian summer monsoon rainfall by West Asian dust. Nat Geosci 7:308-313. doi:10.1038/NGEO2107

Wang C, Kim D, Ekman AML, Barth MC, Rasch PJ (2009) Impact of anthropogenic aerosols on Indian summer monsoon. Geophys Res Lett 36:L21704. doi:10.1029/2009GL040114

Wu G, Liu Y, He B, Bao Q, Duan A, Jin FF (2012) Thermal controls on the Asian Summer Monsoon. Sci Rep. doi:10.1038/srep00404

Zhang J, Christopher SA (2003) Longwave radiative forcing of Saharan dust aerosols estimated from MODIS, MISR, and CERES observations on Terra. Geophys Res Lett 30:2188. doi:10.1029/ 2003GL018479,23

Zhu A, Ramanathan V, Li F, Kim D (2007) Dust plumes over the Pacific, Indian, and Atlantic oceans: climatology and radiative impact. J Geophys Res 112:D16208. doi:10.1029/2007JD008427 